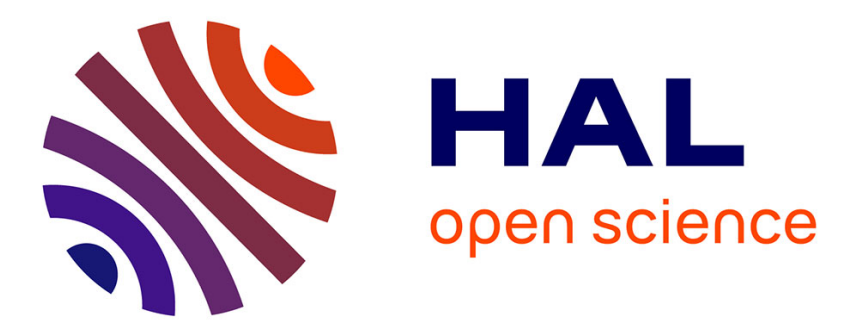

\title{
Metals geochemistry and ecological risk assessment in a tropical mangrove (Can Gio, Vietnam)
}

\author{
Nguyen Thành-Nho, Cyril Marchand, Emilie Strady, Truong-Van Vinh, \\ Tran-Thi Nhu-Trang
}

\section{> To cite this version:}

Nguyen Thành-Nho, Cyril Marchand, Emilie Strady, Truong-Van Vinh, Tran-Thi Nhu-Trang. Metals geochemistry and ecological risk assessment in a tropical mangrove (Can Gio, Vietnam). Chemosphere, 2019, 219, pp.365-382. 10.1016/j.chemosphere.2018.11.163 . hal-02297576

\section{HAL Id: hal-02297576 \\ https://hal.science/hal-02297576}

Submitted on 30 Sep 2019

HAL is a multi-disciplinary open access archive for the deposit and dissemination of scientific research documents, whether they are published or not. The documents may come from teaching and research institutions in France or abroad, or from public or private research centers.
L'archive ouverte pluridisciplinaire HAL, est destinée au dépôt et à la diffusion de documents scientifiques de niveau recherche, publiés ou non, émanant des établissements d'enseignement et de recherche français ou étrangers, des laboratoires publics ou privés. 
5 Nguyen Thanh-Nho ${ }^{1,2}$, Cyril Marchand ${ }^{1,2, *}$, Emilie Strady ${ }^{3,4}$, Truong-Van Vinh ${ }^{2,5}$, Tran-Thi Nhu-Trang ${ }^{1,6}$

1. Department of Analytical Chemistry, Faculty of Chemistry, University of Science, Vietnam National University- Ho Chi Minh

7 City

8 2. IMPMC, Institut de Recherche pour le Développement (IRD), UPMC, CNRS, MNHN, Noumea New Caledonia, France.

9 3. Univ. Grenoble Alpes, CNRS, IRD, Grenoble INP*, IGE, F-38000 Grenoble, France

10 4. CARE-HCMUT, Ho Chi Minh City, Vietnam

11 5. Nong Lam University, Ho Chi Minh City, Vietnam

12 6. Faculty of Chemical Engineering and Food Technology, Nguyen Tat Thanh University, Vietnam.

$13 *$ Corresponding author: Cyril.marchand@ird.fr 
Mangrove sediments act as natural biogeochemical reactors, modifying metals partitioning after their deposition. The objectives of the present study were: to determine distribution and partitioning of metals (Fe, Mn, Ni, Cr, Cu, Co and As) in sediments and pore-waters of Can Gio Mangrove; and to assess their ecological risks based on Risk Assessment Code. Three cores were collected within a mudflat, beneath Avicennia alba and Rhizophora apiculata stands. We suggest that most metals had a natural origin, being deposited in the mangrove mainly as oxyhydroxides derived from the upstream lateritic soils. This hypothesis could be supported by the high proportion of metals in the residual fraction (mean values (\%): 71.9, 30.7, 80.7, 80.9, 67.9, 53.4 and 66.5 for $\mathrm{Fe}, \mathrm{Mn}, \mathrm{Ni}, \mathrm{Cr}$, $\mathrm{Cu}, \mathrm{Co}$, and As respectively, in the mudflat). The enrichment of mangrove-derived organic matter from the mudflat to the Rhizophora stand (i.e. up to $4.6 \%$ of TOC) played a key role in controlling metals partitioning. We suggest that dissolution of Fe and Mn oxyhydroxides in reducing condition during decomposition of organic matter may be a major source of dissolved metals in pore-waters. Only Mn exhibited a potential high risk to the ecosystem. Most metals stocks in the sediments were higher in the Avicennia stand than the Rhizophora stand, possibly because of enhanced dissolution of metal bearing phases beneath later one. In a context of enhanced mangrove forests destruction, this study provides insights on the effects of perturbation and oxidation of sediments on metal release to the environment.

47 Vietnam. 


\section{Introduction}

Mangrove ecosystems are closely tied to anthropogenic activities. Due to their specific characteristics, i.e. their richness in fine particles and organic matter, mangrove sediments can act as natural sinks for metals originating from natural and anthropized watersheds (Clark et al. 1998, Marchand et al. 2011a, Tam and Wong 1996). In mangrove sediments, the partitioning of metals between different phases, i.e. organic matter, iron-manganese oxyhydroxides, sulphides, carbonates (Tam and Wong 1996, Zhang et al. 2014) is strongly influenced by sediment characteristics, i.e. $\mathrm{pH}$, redox potential, particle size (Otero et al. 2009). Accordingly, the mangrove zonation, the hydrological conditions and the presence of different tree species will influence the above characteristics (Marchand et al. 2004, Marchand et al. 2003) which will in turn influence metal accumulation and speciation in the sediments. In fact metals can be released from sediments into pore-waters in suboxic/anoxic conditions by the dissolution of bearing phases (Chakraborty et al. 2016, Marchand et al. 2012) during diagenetic processes, which can subsequently re-precipitate with another bearing phase (Noël et al. 2014). Then, dissolved metals can be exported to adjacent surface waters (Holloway et al. 2016, Sanders et al. 2012) and also be transferred to mangrove's living organism such as fishes, crabs, snails and mangrove's leaves and roots (Chakraborty et al. 2014, De Wolf and Rashid 2008, Parvaresh et al. 2011). In a context of enhanced mangrove forests destruction at a worldwide scale i.e. at a rate close to $1 \%$ per year (Duke et al. 2007), the perturbation and oxidation of sediments can induce the dissolution of sulfide minerals, which can result in sediment acidification (Dent 1986) and can enhance the release of metals from the sediment into the aquatic environment. Thus, the understanding of metal behaviors in mangrove ecosystems is highly relevant for the environment itself but also for human, as mangroves provide important ecosystem services (Lee et al. 2014, M. Brander et al. 2012).

In Vietnam, large mangrove areas were devastated by herbicide mixture during the war in the 70's, and the Can Gio Mangrove was one of the most heavily sprayed areas (Hong 2001, Ross 1975). However, mangrove restoration efforts have been realized and almost 40 years after, the rehabilitated mangrove is now more diverse in community structure than prior to the war (Hong 

2001). Nowadays, this mangrove is largely dominated by Rhizophora apiculata and Avicennia alba species, the latter one developing at lower elevation along tidal creek. The Can Gio Mangrove is located downstream Ho Chi Minh City, the economic capital of Vietnam with almost 10 million inhabitants. Mangrove river network acts as a unique gate for water outlet from Ho Chi Minh City to the South China Sea. Industrial activities, economic developments and rapid population growth are inducing high pressure on water and sediment quality of the adjacent river, the Sai Gon River (Babut et al. 2019, Nguyen et al. 2018, Strady et al. 2017). Strady et al. (2017) stated that the main rivers and canals in the city were moderately contaminated by major metal(oid)s. Recently, ThanhNho et al. (2018) highlighted that metals can be transferred over long distance from upstream to the mangrove forest, and that elevated inputs of metals in the estuary were the result of enhanced runoff and soil leaching during the monsoon season. Consequently, taking into account the mangrove specific geochemical characteristics, the lack of wastewater treatment plants in emerging countries as Vietnam and the important local ecosystem services provided by the Can Gio Mangrove (Cormier-Salem et al. 2017, Kuenzer and Tuan 2013), more attention should be paid on metals distribution, speciation, bioaccumulation and transfer in mangrove ecosystems. We note that so far, in the Can Gio Mangrove, only total metal concentrations in surface water, suspended sediment and surface sediment were investigated (Costa-Boddeker et al. 2017, Thanh-Nho et al. 2018) and the evaluation of the metal speciation in the sediment has not yet been assessed. It can be evaluated by the technique of sequential extraction (Tessier et al. 1979) which provides a classification of metals bound to different geochemical fractions. This technique also allow to characterize the diagenetic processes taking place in the sediment over a depth profile and to characterize the geogenic components and so origin of the sediments.

Within this context, the objectives of this study were: $i$ ) to investigate the geochemistry of $\mathrm{Fe}$, $\mathrm{Mn}, \mathrm{Ni}, \mathrm{Cr}, \mathrm{Cu}, \mathrm{Co}$ and As in sediment cores of the Can Gio Mangrove by focusing on the metal speciation in the sediments and their concentrations in pore-waters; and ii) to assess the potential ecological risks of these metals accumulated in the sediments on the mangrove ecosystem by using Risk Assessment Code (Benson et al. 2017). The sediment cores were sampled on three specific 
environments characterized by different elevation (i.e. tidal inundation), organic matter content,

108 redox stratification and plant cover: in the mudflat, beneath Avicennia stand and beneath

109 Rhizophora stand.

\section{Materials and methods}

\subsection{Study site}

The Can Gio Mangrove (approximately 35,000 ha, extending from $10^{\circ} 22^{\prime}-10^{\circ} 44^{\prime} \mathrm{N}$ and $106^{\circ} 46^{\prime}-107^{\circ} 01^{\prime} \mathrm{E}$ (Tuan and Kuenzer 2012)) is located in the south of Vietnam, at the downstream part of the Sai Gon and Dong Nai Rivers watershed and in the South China Sea coastal zone (Fig. 1). It is a Biosphere Reserve of UNESCO since 2000 and it is also a well-known example of "mangrove afforestation and reforestation area" (Blasco et al. 2001). The Can Gio Mangrove is home to more than 20 mangrove species with two dominant ones: Rhizophora apiculata and Avicennia alba (Luong et al. 2015), and 200 species of fauna (e.g. amphibians, fishes, benthic organisms, etc.). The main economic activities of the local people are forest management, aquaculture, fishing and salt production (Kuenzer and Tuan 2013). The Can Gio Mangrove is subject to the typical tropical monsoon climate, with two distinct seasons. The dry season lasts from November to April and the monsoon season from May to October. The annual mean precipitation is about 1,300 to $1,400 \mathrm{~mm}$, with $\sim 90 \%$ of the precipitation falling during the monsoon season and the annual mean temperature ranges from $26.5^{\circ} \mathrm{C}$ to $30^{\circ} \mathrm{C}$. It is also subject to a semi-diurnal tidal regime. The topography of the Can Gio Mangrove is generally low-lying. Average vertical accretion rates in the Can Gio Mangrove are similar between fringe $\left(1.06 \pm 0.12 \mathrm{~cm}^{\text {year }}{ }^{-1}\right)$ and interior mangrove $\left(0.99 \pm 0.09 \mathrm{~cm}\right.$ year $\left.^{-1}\right)$ (MacKenzie et al. 2016). The sediment is composed of alluvial deposits and lateritic soils (Luong 2011) from the Sai Gon and Dong Nai Rivers. The lateritic soils originate from the physico-chemical weathering of basaltic rocks in the Central Highland of Vietnam (Egawa and Ooba 1963). 


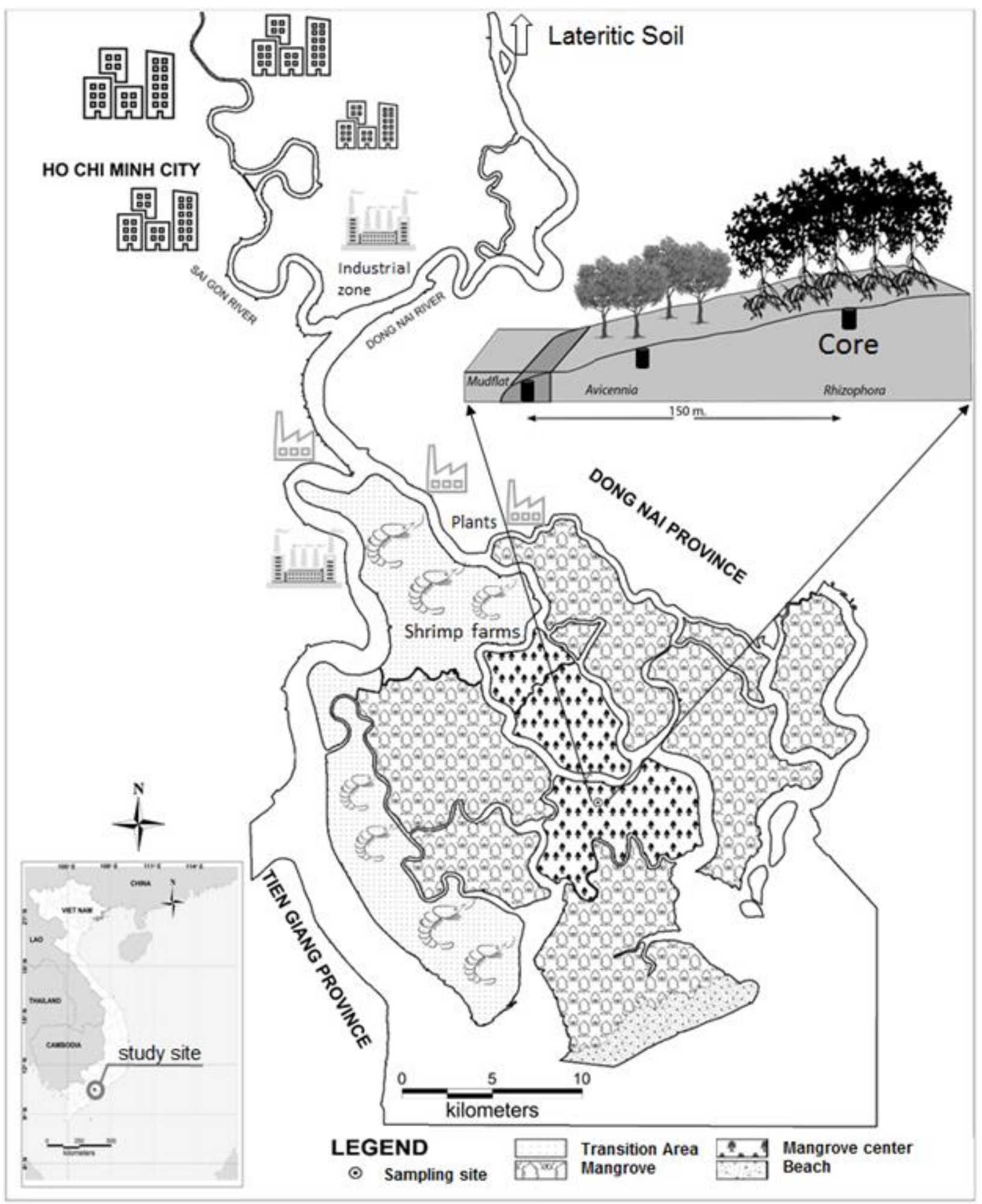

Fig. 1. Location of the Can Gio Mangrove and the three cores $(90 \mathrm{~cm}$ depth) collected in the mudflat, beneath the Avicennia stand and the Rhizophora stand.

\subsection{Sample collections and preservations}

Sampling was carried out in the center area of the Can Gio Mangrove during the monsoon season (October 2016). Three cores (90 cm depth) were collected with an Eijkelkamp gouge auger at low tide in the mudflat (lower elevation than the mangrove stands), beneath an Avicennia alba 
stand and a Rhizophora apiculata stand (Fig. 1). Cores were immediately sectioned into 10 samples: every $5 \mathrm{~cm}$ from the surface to $30 \mathrm{~cm}$ depth, every $10 \mathrm{~cm}$ from 30 to $50 \mathrm{~cm}$ depth, and every $20 \mathrm{~cm}$ from 50 to $90 \mathrm{~cm}$ depth. Samples were stored in polythene bags, preserved in a cooler box for their transfer to the laboratory and were then stored frozen $\left(-20^{\circ} \mathrm{C}\right)$ until drying. Dried samples were grinded using an agate pestle and mortar, and sieved using $100 \mu \mathrm{m}$ pore size for sequential extraction of metals fractions and for total organic carbon (TOC) analysis.

For dissolved metal analysis, pore-waters were extracted on the day of coring with soil moister sampler Rhizon ${ }^{\circledR}$, which were directly inserted into the center of the cores (Marchand et al. 2012). All samples were then filtered through $0.45 \mu \mathrm{m}$ Sartorius ${ }^{\circledR}$ filter membranes and acidified to $\mathrm{pH}<$ 2 by Suprapur ${ }^{\circledR}$ concentrated $\mathrm{HNO}_{3}$ (Merck). The samples were then preserved in cleaned $14 \mathrm{ml}$ polypropylene (PP) tubes at $4{ }^{\circ} \mathrm{C}$ until analysis.

\subsection{Analytical methods and calculations}

\subsubsection{Salinity, $p H$ and redox measurements}

Additional cores beneath each mangrove stand and in the mudflat were collected to measure salinity, $\mathrm{pH}$ and redox. These parameters were measured in-situ. Salinities were determined using an ATAGO refractometer (S-10, Japan) after extracting a drop of pore-water from each sediment layer. $\mathrm{pH}$ was measured using a glass electrode (pH 3110-WTW), which was pre-calibrated using pH 4, 7 and 10 standard buffer solutions (NIST scale). Redox potential was measured using digital voltmeter with $\mathrm{Pt}$ and $\mathrm{Ag} / \mathrm{AgCl}$ (reference) electrode connected to $\mathrm{pH} / \mathrm{mV} / \mathrm{T}$ meter ( $\mathrm{pH} 100-\mathrm{YSI}$ ), which was periodically checked using $0.43 \mathrm{~V}$ standard solution and deionized water. Redox data are reported relative to a standard hydrogen electrode i.e. after adding $194 \mathrm{mV}$ to the original $\mathrm{mV}$ values obtained with an $\mathrm{Ag} / \mathrm{AgCl}$ (reference electrode) at $30^{\circ} \mathrm{C}$. The redox scale was fully described by Marchand et al. (2011a), as follows: (i) oxic > $400 \mathrm{mV}$, containing measurable dissolved oxygen; (ii) $100 \mathrm{mV}<$ suboxic $<400 \mathrm{mV}$, with a lack of measurable oxygen or sulfide, containing dissolved iron or manganese, with no reduction of sulfate; (iii) anoxic $<100 \mathrm{mV}$, with sulfate reduction.

\subsubsection{Metal concentrations in pore-waters}


Dissolved $\mathrm{Fe}, \mathrm{Mn}, \mathrm{Ni}, \mathrm{Cr}, \mathrm{Cu}, \mathrm{Co}$ and As concentrations were directly measured by Thermo

Scientific iCAPQ ICP-MS with a Kinetic Energy Discrimination-Argon Gas Dilution module (KED - AGD mode) (Kutscher et al. 2014) using internal standard calibration (AETE-ISO platform, OSU-OREME/Université de Montpellier). Accuracy and precision were controlled using the certified reference material SLEW-3 (Table 1a).

Table 1. Quality control of analytical methods applied for dissolved and total metals concentrations analysis respectively: a) accuracy, precision and detection limit using estuarine water $S L E W-3$; b) total metal concentrations were calculated by summing the four single fraction $(F 1+F 2+F 3+F 4)$ from CRM $(B C R-277 R)$.

a) Dissolved metal concentration analysis.

\begin{tabular}{|c|c|c|c|c|c|}
\hline Element & $\begin{array}{l}\text { Detection limit } \\
\qquad\left(\mu g L^{-1}\right)\end{array}$ & $\begin{array}{l}\text { Certificated values } \\
\text { of SLEW-3 }\left(\mu g L^{-1}\right)\end{array}$ & $\begin{array}{l}\text { Measured values } \\
(\mu g L-1)\end{array}$ & $\begin{array}{c}\text { Recovery } \\
(\%)\end{array}$ & $\begin{array}{c}\text { Relative standard deviation } \\
\text { (\%) }\end{array}$ \\
\hline $\mathrm{Fe}$ & 0.031 & $0.568 \pm 0.059$ & $0.661 \pm 0.073$ & 116 & 11 \\
\hline $\mathrm{Mn}$ & 0.013 & $1.61 \pm 0.22$ & $1.469 \pm 0.016$ & 91 & 1 \\
\hline $\mathrm{Ni}$ & 0.011 & $1.23 \pm 0.07$ & $1.230 \pm 0.014$ & 100 & 1 \\
\hline $\mathrm{Cr}$ & 0.022 & $0.183 \pm 0.019$ & $0.0182 \pm 0.020$ & 99 & 11 \\
\hline $\mathrm{Cu}$ & 0.011 & $1.55 \pm 0.12$ & $1.491 \pm 0.041$ & 96 & 3 \\
\hline Co & 0.0092 & $0.042 \pm 0.010$ & $0.0464 \pm 0.0025$ & 110 & 5 \\
\hline As & 0.0062 & $1.36 \pm 0.09$ & $1.569 \pm 0.013$ & 115 & 1 \\
\hline
\end{tabular}

b) Total metal concentration analysis

\begin{tabular}{|c|c|c|c|c|c|}
\hline Element & $\begin{array}{l}\text { Certificated values of } B C R-277 R \\
\qquad\left(\mathrm{mg} \mathrm{kg}^{-1}\right)\end{array}$ & $\begin{array}{l}\text { Measured values } \\
\left(\mathrm{mg} \mathrm{kg}^{-1}, \mathrm{n}=9\right)\end{array}$ & $\begin{array}{l}\text { Recovery } \\
(\%)\end{array}$ & $\begin{array}{l}\text { Relative standard } \\
\text { deviation (\%) }\end{array}$ & $\begin{array}{l}\text { Analytical } \\
\text { method }\end{array}$ \\
\hline $\mathrm{Fe}$ & NA & $50,843 \pm 3,029$ & - & 5.8 & FAAS \\
\hline $\mathrm{Mn}$ & NA & $897 \pm 37$ & - & 4.2 & FAAS \\
\hline $\mathrm{Ni}$ & $130 \pm 8$ & $125.9 \pm 6.1$ & 96.9 & 4.9 & ICP-MS \\
\hline $\mathrm{Cr}$ & $188 \pm 14$ & $179.9 \pm 16.1$ & 95.7 & 9 & ICP-MS \\
\hline $\mathrm{Cu}$ & $63 \pm 7$ & $58.9 \pm 4.6$ & 93.6 & 7.9 & ICP-MS \\
\hline Co & $22.5 \pm 1.4$ & $23.1 \pm 1.7$ & 102.6 & 7.5 & ICP-MS \\
\hline As & $18.3 \pm 1.8$ & $18.1 \pm 1.5$ & 98.9 & 8.2 & ICP-MS \\
\hline
\end{tabular}

\subsubsection{Sequential extraction: metal fractions}

To evaluate the geochemistry and availability of metals (Fe, Mn, Ni, $\mathrm{Cr}, \mathrm{Cu}, \mathrm{Co}$ and $\mathrm{As}$ ) in the sediment cores, a sequential extraction procedure was carried out based on the method developed by Tessier et al. (1979) and Ure et al. (1993). Each element was divided into four operationallydefined geochemical fractions: exchangeable/carbonate fraction (acid-soluble phase), $\mathrm{Fe}-\mathrm{Mn}$ oxides fraction (reducible phase), organic fraction (oxidizable phase) and a residual fraction. Briefly, the various single extractions were performed as following: $1 \mathrm{~g}$ of fine dry sediments were 
put into $50 \mathrm{~mL}$ PP tubes with caps, which were also used for shaking time and centrifugation to minimize the possible loss of the centrifuge - washing step. For the determination of the acidsoluble fraction (F1), we used $8 \mathrm{~mL}$ of $1 \mathrm{M}$ buffer acidic solution $\left(\mathrm{CH}_{3} \mathrm{COOH} / \mathrm{CH}_{3} \mathrm{COONH}_{4}, \mathrm{pH}\right.$ = 5) at room temperature during $5 \mathrm{~h}$; for the reducible fraction (F2), we used $20 \mathrm{~mL}$ of $0.04 \mathrm{M}$ $\mathrm{NH}_{2} \mathrm{OH} . \mathrm{HCl}$ in $25 \% \mathrm{CH}_{3} \mathrm{COOH}(\mathrm{m} / \mathrm{v})$ at $96{ }^{\circ} \mathrm{C}$ during $6 \mathrm{~h}$; for the oxidizable fraction $(\mathrm{F} 3)$, we used $3 \mathrm{~mL}$ of $0.02 \mathrm{M} \mathrm{HNO}_{3}$ and $8 \mathrm{~mL}$ of $30 \% \mathrm{H}_{2} \mathrm{O}_{2} .5 \mathrm{~mL}$ of $3.2 \mathrm{M} \mathrm{CH}_{3} \mathrm{COONH}_{4}$ was added into the solution to prevent reabsorb of these metals onto particles surface; for the total metals concentration in the residual fraction (F4), the samples was digested using $10 \mathrm{~mL}$ of concentrated $\mathrm{HNO}_{3} / \mathrm{HCl} / \mathrm{HF}(3: 1: 1=v / v)$ in polytetrafluoroethylene (PTFE) vessel at $110{ }^{\circ} \mathrm{C}$ for $48 \mathrm{~h}$. After cooling, $2 \mathrm{~mL}$ of concentrated $\mathrm{HNO}_{3}(\mathrm{n}=2)$ was added into these samples for eliminating residual HF. For each adding, the solution were evaporated near to dryness at $160{ }^{\circ} \mathrm{C}$. The samples were filtrated and adjusted using deionized water into $25 \mathrm{~mL}$, and were then stored in pre-cleaned polypropylene tubes at $4{ }^{\circ} \mathrm{C}$ until analysis.

\subsubsection{Total metal concentration}

Total metal concentrations were obtained by summing the four single fractions $(\mathrm{F} 1+\mathrm{F} 2+\mathrm{F} 3$ + F4). The quantifications of $\mathrm{Fe}$ and $\mathrm{Mn}$ concentrations were performed by Flame Atomic Absorption (Shimadzu AA-6650) while the other metals (Co, Ni, Cu, As and Cr) were analyzed by ICP-MS (Agilent 7700x) using spiked ${ }^{103} \mathrm{Rh}$ and ${ }^{197} \mathrm{Au}$ as internal standard (Table 1b). The analytical precision and accuracy were insured by analyzing certified reference material estuarine sediment (BCR-277R) intercalated in each batch of sample digestion. All reagents were analysis grade (Merck) and all containers were de-contaminated by soaking in $5 \%$ nitric acid for $24 \mathrm{~h}$ and rinsed in deionized water.

\subsubsection{Total organic carbon (TOC)}

TOC analysis was carried out on a Shimadzu ${ }^{\circledR}$ TOC-L series analyzer combined with a solid sample module (SSM-5000A) heating at $900{ }^{\circ} \mathrm{C}$. Glucose standard (40\%, Sigma Aldrich) was used for calibrations. Repeated measurements of the standards at different concentrations indicated a measurement deviation $<2 \%$. 
The bulk density is defined as the ratio of dry sediment mass to sediment volume (including pore space) and is typically expressed in $\mathrm{g} \mathrm{cm}^{-3}$. The sediment bulk density was calculated for each layer (i.e. every $5 \mathrm{~cm}$ from 0 to $30 \mathrm{~cm}$ depth and every $10 \mathrm{~cm}$ from 30 to $50 \mathrm{~cm}$ depth) of the three cores (i.e. the mudflat, the Avicennia and the Rhizophora stands) by taking subsamples of known volume sediment, drying them at $45^{\circ} \mathrm{C}$ during $24 \mathrm{~h}$ and by weighing them.

The determination of the metal stocks may help to understand if a mangrove stand can be a sink or a source of metals, by taking into account that diagenetic processes influence the stocks. of bearing phases, and thus to metals export to adjacent tidal creek and/or subject to plant uptake. Thus, the metal stocks present in the Can Gio Mangrove sediment were estimated from the average total metal concentrations and average bulk density determined in each core from surface to $50 \mathrm{~cm}$ depth (e.g. the depth was chosen at $50 \mathrm{~cm}$ depth in order to compare it to the estimated stocks from the literature), according to the following equation.

$$
\text { Metal Stock }\left(\mathrm{t} \mathrm{ha}^{-1}\right)=\left(\mathrm{C}_{\text {sediment }} * \mathrm{BD} * 50 * 100\right) / 10^{6}
$$

where:

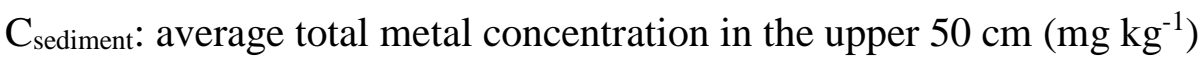

BD: average bulk density in the upper $50 \mathrm{~cm}\left(\mathrm{~g} \mathrm{~cm}^{-3}\right)$

50: length of the core used for estimation of metal stock $(\mathrm{cm})$

100: conversion factor from $\mathrm{g} \mathrm{cm}^{-2}$ to $\mathrm{tha}^{-1}$

$10^{6}$ : conversion factor of a metal concentration in $\mathrm{mg} \mathrm{kg}^{-1}$

\subsubsection{Data analysis}

Pearson correlation coefficients were performed using statistical package software (SPSS: version 23) to identify major relationships between metal concentrations and physico-chemical parameters as well as interrelationships between metals together. 


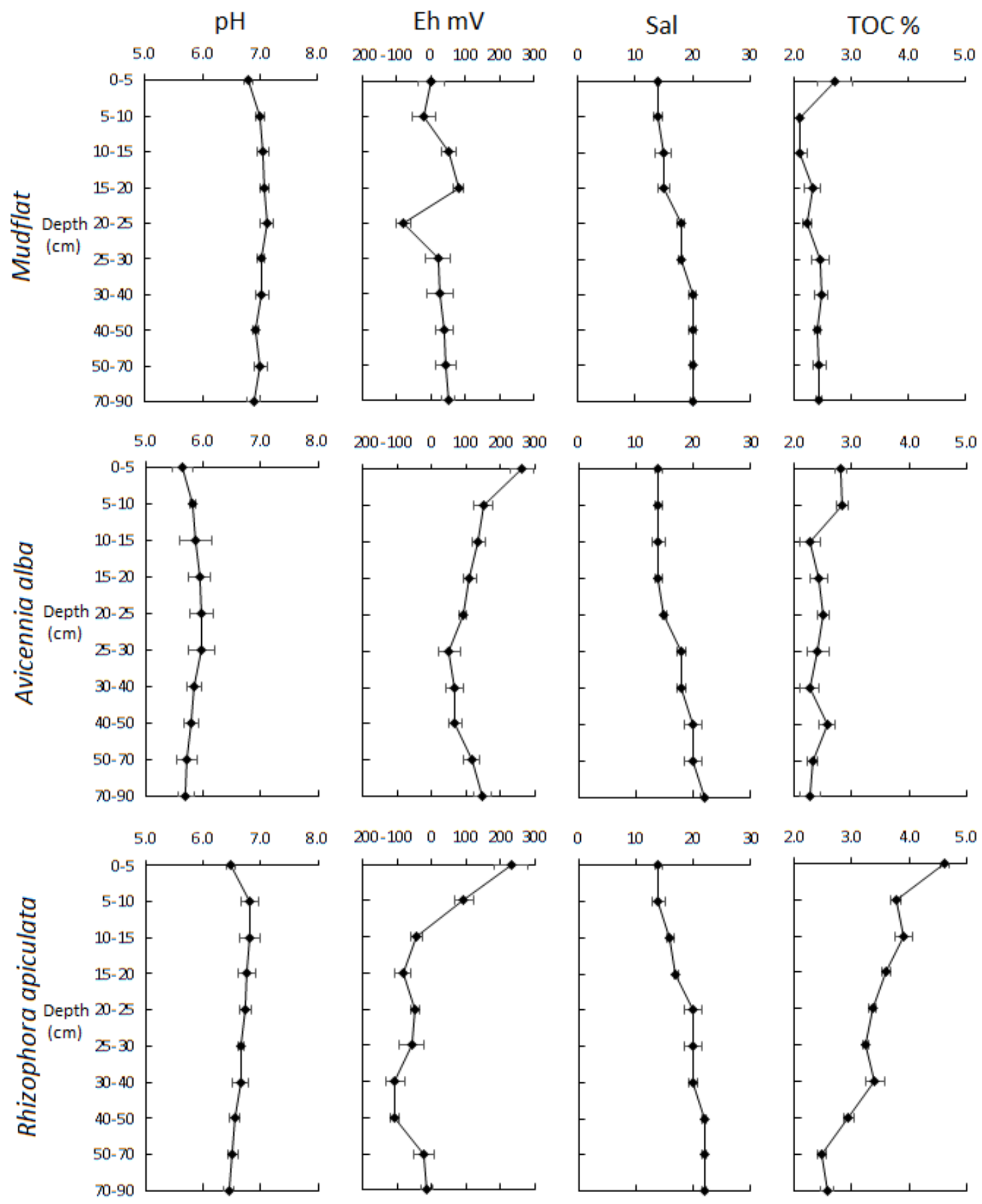

Fig. 2. Depth distributions of $p H$, Eh, Salinity and TOC in the mudflat, the Avicennia and the Rhizophora stands

\section{Results}

in the Can Gio Mangrove.

\subsection{Physico-chemical parameters in the sediment cores}

The depth evolutions of $\mathrm{pH}$, redox potential (Eh), salinity and total organic carbon (TOC) in

243 the sites, being lower in the Avicennia stand (5.6 to 6.0) than in the Rhizophora stand (6.5 to 6.8)

244 and in the mudflat (6.8 to 7.1). Eh distributions and values differed in the three environments. The 
mudflat was characterized by anoxic condition in whole core, ranging between $73 \mathrm{mV}$ and $-88 \mathrm{mV}$.

The sediments beneath mangroves stands were characterized from suboxic to anoxic conditions toward the bottom of the cores. In the Avicennia stand, Eh values decreased from $254 \mathrm{mV}$ at the top of the core to $43 \mathrm{mV}$ at $30 \mathrm{~cm}$ depth, and then slightly increased without being higher than 140 $\mathrm{mV}$. In the Rhizophora stand, redox values decreased from the top of the core $(224 \mathrm{mV})$ to $20 \mathrm{~cm}$ depth $(-90 \mathrm{mV})$ and then fluctuated between of $-20 \mathrm{mV}$ to $-115 \mathrm{mV}$. Salinity increased with depth in the three cores with similar distribution patterns, from 14 to 22 . TOC contents varied with depth in the mudflat (from $2.7 \%$ to $2.1 \%$ ) and in the Avicennia stand (from $2.8 \%$ to $2.3 \%$ ) without specific distributions patterns, while in the Rhizophora stand TOC concentrations were higher than in the other sites, and decreased with depth (from $4.62 \%$ to $2.1 \%$ ).

\subsection{Total metal concentrations in the sediment cores}

The total metal concentrations ( $\mathrm{Fe}, \mathrm{Mn}, \mathrm{Ni}, \mathrm{Cr}, \mathrm{Cu}, \mathrm{Co}$ and $\mathrm{As}$ ) in the three cores were obtained by summing the four single fraction (i.e. F1 + F2 + F3 + F4). The depth's distribution of each metal in the mudflat, the Avicennia stand, the Rhizophora stand and their mean concentrations are presented in Fig. 3 and supplementary data (Table SD).

Total $\mathrm{Fe}$ concentrations did not exhibit specific distribution with depth in the three environments. The mean values of total Fe concentration decreased from the mudflat $(53,146 \pm$ $\left.1,422 \mathrm{mg} \mathrm{kg}^{-1}\right)$ to the mangrove stands $\left(49,305 \pm 2,198 \mathrm{mg} \mathrm{kg}^{-1}\right.$ and $47,135 \pm 2,370 \mathrm{mg} \mathrm{kg}^{-1}$ in the Avicennia stand and Rhizophora stand, respectively). The total Mn concentrations decreased with depth in each environment, from $653 \mathrm{mg} \mathrm{kg}^{-1}$ to $310 \mathrm{mg} \mathrm{kg}^{-1}$ in the mudflat, from $800 \mathrm{mg} \mathrm{kg}^{-1}$ to $227 \mathrm{mg} \mathrm{kg}^{-1}$ in the Avicennia stand and from $350 \mathrm{mg} \mathrm{kg}^{-1}$ to $160 \mathrm{mg} \mathrm{kg}^{-1}$ in the Rhizophora stand. Total $\mathrm{Ni}$ and $\mathrm{Cr}$ concentrations presented small amplitude with depth in the three environments but their mean concentrations in each core evidenced higher mean values in the Avicennia and Rhizophora stands $\left(62.5 \pm 2.6 \mathrm{mg} \mathrm{kg}^{-1}\right.$ and $61.1 \pm 1.7 \mathrm{mg} \mathrm{kg}^{-1}$ for $\mathrm{Ni} ; 95.3 \pm 1.4 \mathrm{mg} \mathrm{kg}^{-1}$ and 95.8 $\pm 4.2 \mathrm{mg} \mathrm{kg}^{-1}$ for $\mathrm{Cr}$, respectively) than in the mudflat $\left(52.7 \pm 3.7 \mathrm{mg} \mathrm{kg}^{-1}\right.$ for $\mathrm{Ni}$ and $86.6 \pm 3.8 \mathrm{mg}$ $\mathrm{kg}^{-1}$ for $\mathrm{Cr}$ ). Total Co concentrations showed similar distributions between environments, being stable values in the upper horizons from 0 to $40 \mathrm{~cm}$ depth and then increasing to reach a maximum 
272 values of $24.2 \mathrm{mg} \mathrm{kg}^{-1}, 29.7 \mathrm{mg} \mathrm{kg}^{-1}$ and $25.8 \mathrm{mg} \mathrm{kg}^{-1}$ in the mudflat, the Avicennia stand and the

273 Rhizophora stand, respectively. Finally, total As and $\mathrm{Cu}$ concentrations did not present any specific

274 vertical distribution patterns, and their mean concentrations were similar to all environments

275 (supplementary data, Table SD).
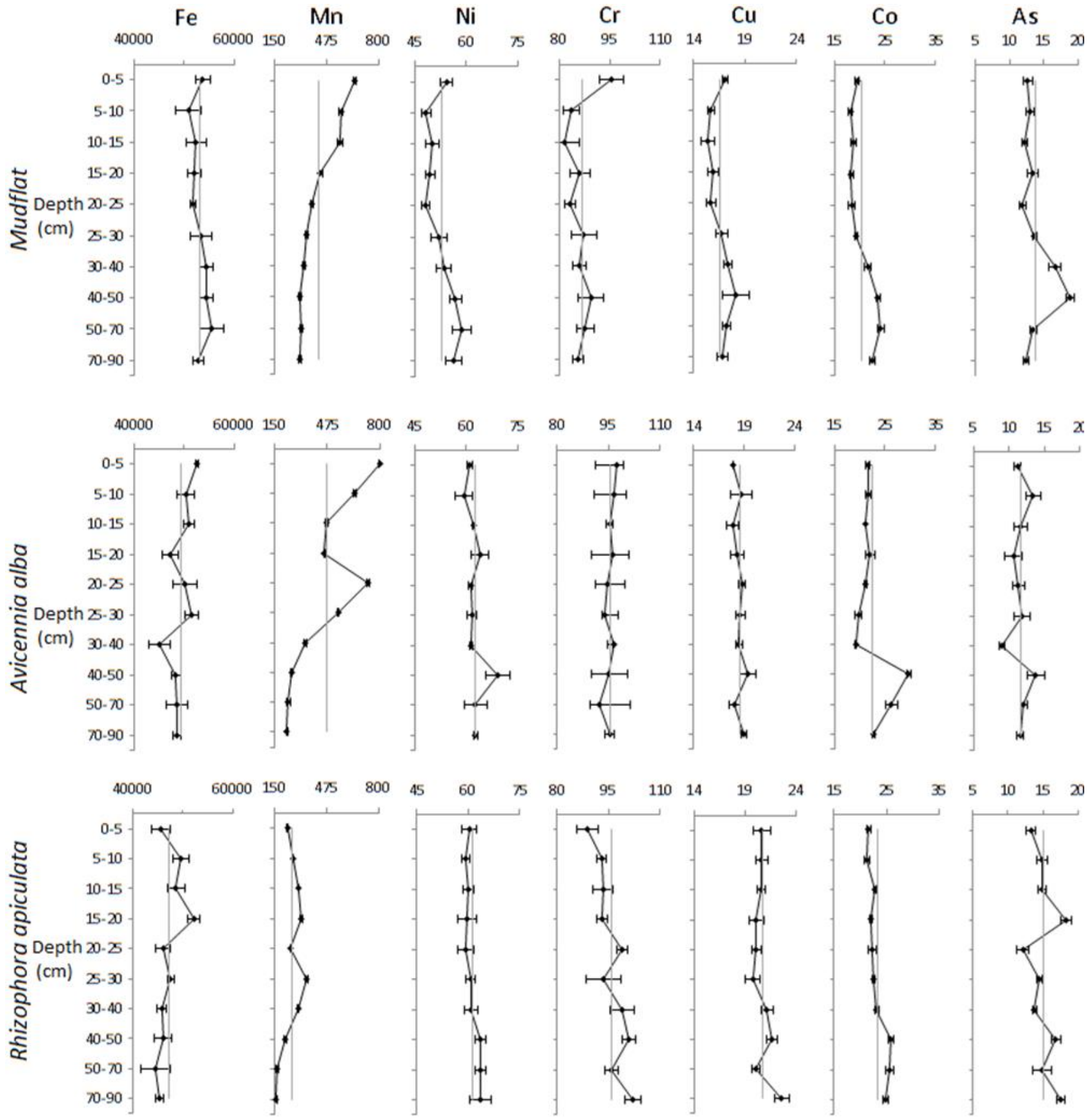

Fig. 3. Vertical distributions of metals concentrations (square dots) in the mudflat, the Avicennia stand and the Rhizophora stand (expressed in $\mathrm{mg} \mathrm{kg}^{-1}$ ), with gray line presenting mean metal concentrations of each core.

\subsection{Metal stock estimation}

The metal stocks were estimated over the $50 \mathrm{~cm}$ depth profile of the cores. Interestingly, the metal stocks differed between the mangrove stands and the mudflat (Table 2). The Fe stock 
presented decreasing values from the mudflat $\left(169.2 \pm 4.2 \mathrm{t} \mathrm{ha}^{-1}\right)$ to the inner mangrove (i.e. the Rhizophora stand, $\left.126.4 \pm 6.2 \mathrm{tha}^{-1}\right)$. Conversely, the stock of Mn was higher beneath the Avicennia stand $\left(1.62 \pm 0.57 \mathrm{t} \mathrm{ha}^{-1}\right)$ than in the mudflat $\left(1.44 \pm 0.41 \mathrm{t} \mathrm{ha}^{-1}\right)$ and was even lower in the Rhizophora stand $\left(0.74 \pm 0.12 \mathrm{tha}^{-1}\right)$. Except As stock, which was higher in the mudflat, the stocks of $\mathrm{Co}, \mathrm{Ni}, \mathrm{Cr}$ and $\mathrm{Cu}$ showed higher values in the Avicennia stand than in the Rhizophora zone and in the mudflat. They varied (expressed in $\mathrm{t} \mathrm{ha}^{-1}$ ) from $0.16 \pm 0.004$ to $0.19 \pm 0.01$ for $\mathrm{Ni}$, from 0.25 \pm 0.01 to $0.29 \pm 0.003$ for $\mathrm{Cr}$, and from $0.053 \pm 0.003$ to $0.057 \pm 0.002$ for $\mathrm{Cu}$, from $0.060 \pm 0.004$ to $0.067 \pm 0.010$ for $\mathrm{Co}$, from $0.035 \pm 0.005$ to $0.045 \pm 0.008$ for As.

Table 2. Metal stocks in the sediments of the mudflat, the Avicennia stand and the Rhizophora stand in the Can Gio Mangrove (expressed in tha-1, values were obtained based on the average total metal concentration and average bulk density of each core on $50 \mathrm{~cm}$ depth). The metal stocks beneath Avicennia and Rhizophora stands were compared with those measured in the mudflat (\%).

\begin{tabular}{lcccccccc}
\hline Stand & Bulk density $\left(\mathrm{g} \mathrm{cm}^{-3}\right)$ & $\mathrm{Fe}$ & $\mathrm{Mn}$ & $\mathrm{Ni}$ & $\mathrm{Cr}$ & $\mathrm{Cu}$ & $\mathrm{Co}$ & $\mathrm{As}$ \\
\hline Mud flat & 0.64 & $169.2 \pm 4.2$ & $1.44 \pm 0.41$ & $0.16 \pm 0.01$ & $0.28 \pm 0.01$ & $0.053 \pm 0.003$ & $0.063 \pm 0.006$ & $0.045 \pm 0.008$ \\
Avicennia & 0.61 & $150.9 \pm 7.5$ & $1.62 \pm 0.57$ & $0.19 \pm 0.01$ & $0.29 \pm 0.003$ & $0.057 \pm 0.002$ & $0.067 \pm 0.010$ & $0.035 \pm 0.005$ \\
(\% mud flat) & & 89 & 112 & 116 & 105 & 107 & 106 & 79 \\
$\begin{array}{l}\text { Rhizophora } \\
\text { (\% mud flat) }\end{array}$ & 0.53 & $126.4 \pm 6.2$ & $0.74 \pm 0.12$ & $0.16 \pm 0.004$ & $0.25 \pm 0.01$ & $0.055 \pm 0.002$ & $0.060 \pm 0.004$ & $0.039 \pm 0.005$ \\
& & 75 & 51 & 97 & 91 & 103 & 95 \\
\hline
\end{tabular}

\subsection{Metal partitioning in the sediment cores}

The metals (Fe, Mn, Ni, Cr, Cu, Co and As) partitioning in each layer of sediment core collected in the mudflat, the Avicennia stand and the Rhizophora stand was determined based on their concentrations in the exchangeable/carbonate fraction $(\mathrm{F} 1)$, the oxides fraction $(\mathrm{F} 2)$, the organic fraction (F3) and the residual fraction (F4). Their respective percentages/ proportions in each phase were evaluated based on their total concentrations (i.e. summing of metal concentrations in four fractions), being presented in Fig. 4.

\subsubsection{Fe and $\mathrm{Mn}$}

The Fe and Mn partitioning exhibited different vertical distributions according to environments. In the mudflat and in the Avicennia stand, the Fe partitioning was F4 > F2 > F3 F1 (Fig. 4a) whereas for Mn it was: F4 F1 > F2 > F3 (Fig. 4b). Fe in F4 was stable with depth, representing $72 \%$ in the mudflat and $78 \%$ in the Avicennia stand, whereas Mn in F4 increased with depth, from $22 \%$ to $38 \%$ in the mudflat and from $18 \%$ to $62 \%$ in the Avicennia stand. Mn was characterized 
by an important exchangeable/carbonate fraction, which decreased from $42 \%$ to $27 \%$ in the mudflat and from $51 \%$ to $22 \%$ in the Avicennia stand. F2 of both Fe and Mn decreased with depth in the mudflat and in the Avicennia stand, respectively from $20 \%$ to $12 \%$ and $20 \%$ to $12 \%$ for $\mathrm{Fe}$, and respectively from $42 \%$ to $27 \%$ and $51 \%$ to $22 \%$ for Mn. F3 of Fe and Mn presented increasing values with depth in the mudflat, from $8 \%$ to $15 \%$ for Fe and from $6 \%$ to $13 \%$ for Mn, while it is stable in the Avicennia stand with a mean value of $3 \%$ for Fe and values ranging from $2 \%$ to $6 \%$ for Mn. F1 of Fe was stable with depth with mean values of $2 \%$ and $3 \%$ in the mudflat and in the Avicennia stand, respectively.

In the Rhizophora stand, Fe and Mn exhibited the same partitioning: F4 > F3 > F2 > F1. The residual fraction was stable from the top to the $40 \mathrm{~cm}$ depth, and then gradually increased with depth from $62 \%$ to $78 \%$ for Fe and from $35 \%$ to $66 \%$ for Mn. The organic fraction of both Fe and Mn was higher in the Rhizophora stand than in the Avicennia stand and the mudflat. Conversely to $\mathrm{F} 4$, the proportion of $\mathrm{Fe}$ and $\mathrm{Mn}$ in $\mathrm{F} 3$ increased from the top to $40 \mathrm{~cm}$ depth (i.e. ranging from 18 to $36 \%$ for $\mathrm{Fe}$ and 21 to $54 \%$ for $\mathrm{Mn}$ ), then decreased to the bottom of the core (i.e. ranged from 35 to $16 \%$ and from 52 to $17 \%$ for Fe and Mn, respectively). Fe and Mn in F2 decreased toward the bottom of the core, from $15 \%$ to $3 \%$ for Fe and from $23 \%$ to $8 \%$ for Mn. Eventually, the exchangeable/carbonate fraction of Fe represented less than $1 \%$ of total Fe concentrations, while F1 of Mn decreases with depth from $16 \%$ to $3 \%$.

\subsubsection{Ni, $\mathrm{Cr}, \mathrm{Cu}, \mathrm{Co}$ and $\mathrm{As}$}

The Ni partitioning was characterized by F4 $>$ F2 $\sim$ F3 $>$ F1 in the mudflat and the Avicennia stand and by F4 > F3 > F2 > F1 in the Rhizophora stand (Fig. 4c). F4 was in the same range (from $76 \%$ to $84 \%$ ) in the mudflat and in the Rhizophora stand, but higher (from $83 \%$ to $91 \%$ ) in the Avicennia stand, without clear vertical distributions in all cores. F3 was stable with depth and presented a higher proportion in the Rhizophora stand $(11 \%)$ than in the mudflat $(8 \%)$ and in Avicennia stand (5\%). F2 and F1 were stable with depth at all sites, and represented less than $8 \%$ for F2 and less than $3 \%$ for F1. 
The Cr partitioning was F4 > F3 > F2 > F1, without any clear depth evolution (Fig. 4d). The

residual fraction ranged from $78 \%$ and $84 \%$ in the mudflat and the Avicennia stand and from 72 $\%$ to $79 \%$ in the Rhizophora stand. The organic fraction was characterized by higher proportion in the Rhizophora stand (16\% to $24 \%$ ) than in the mudflat (11\% to $17 \%)$ and in the Avicennia stand (10\% to $13 \%)$. The oxides fraction and the exchangeable/carbonate fraction presented low proportion (less than $5 \%$ ) and same range of values in all environments.

The $\mathrm{Cu}$ partitioning differed between sites: $\mathrm{F} 4>\mathrm{F} 3>\mathrm{F} 1>\mathrm{F} 2$ in the mudflat, $\mathrm{F} 4>\mathrm{F} 3>\mathrm{F} 2 \sim$ F1 in the Avicennia stand, and F4 > F3 > F2 > F1 in the Rhizophora stand (Fig. 4e). For the F4, the proportion of $\mathrm{Cu}$ was higher in the Avicennia stand (85\% to $94 \%$ ) than in the Rhizophora stand (44\% to $73 \%$ ) and in the mudflat ( $57 \%$ to $75 \%$ ). In the mudflat, the proportion of $\mathrm{Cu}$ in $\mathrm{F} 4$ decreased with depth while no specific distribution was observed beneath the mangrove stands. F3 ranged from $24 \%$ to $41 \%$ in the mudflat and Rhizophora stand, and from $6 \%$ to $14 \%$ in the Avicennia stand. F1 and F2 fractions were characterized by low proportion $(<2 \%)$ in all environments except in the Rhizophora stand where the F2 increased from $20 \mathrm{~cm}$ depth until the bottom of the core.

The Co partitioning also differed between cores: F4 > F2 F3 > F1 in the mudflat, F4 > F2 > $\mathrm{F} 1 \sim \mathrm{F} 3$ in the Avicennia stand and F4 $>$ F3 $>$ F2 $>$ F1 in the Rhizophora stand (Fig. 4f). The residual fraction was closed to $50 \%$ in both the mudflat and the Rhizophora stand, but ranging from $50 \%$ to $76 \%$ in the Avicennia stand with lower proportion at depth. F3 presented opposite pattern than F4 in the mudflat and the mangrove stands. F2 and the F1 were stable in all environments with lower proportion in the Rhizophora stand for F2 and increasing F1 proportion from $40 \mathrm{~cm}$ depth in the Avicennia stand.

The As partitioning was F4 $>$ F2 $>$ F3 $>$ F1 in the mudflat, $\mathrm{F} 4>\mathrm{F} 2>\mathrm{F} 3 \sim \mathrm{F} 1$ in the Avicennia stand and F4 > F2 F3 > F1 in the Rhizophora stand (Fig. 4g). In the upper part of the core in the mudflat (to $25 \mathrm{~cm}$ depth), all fractions presented stable proportions. Then, As in F3 and F4 increased with depth while As in F1 and F2 decreased. In the core beneath the Avicennia stand, As proportion in F4 gradually decreased from the top to the $40 \mathrm{~cm}$ depth and dramatically increased 
361 specific distribution along the core. In the Rhizophora stand, the residual and the organic fractions

362 were stable from the top of the core to $40 \mathrm{~cm}$ depth, then F4 increased toward the bottom while F3

363 decreased. The F2 and F1 fraction did not exhibit any specific distribution along the core.

(a) $\mathrm{Fe}$

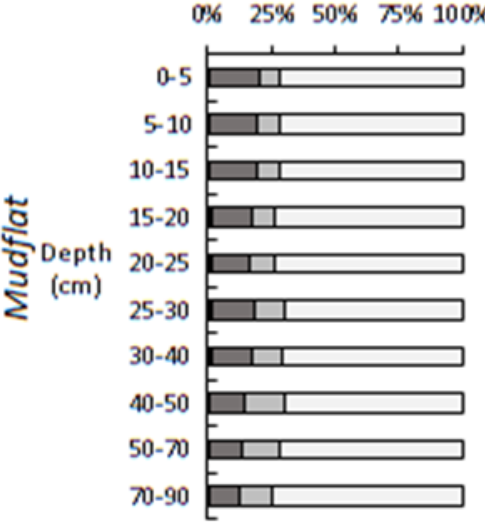

$0 \% \quad 25 \% \quad 50 \% \quad \pi \% \quad 100 \%$

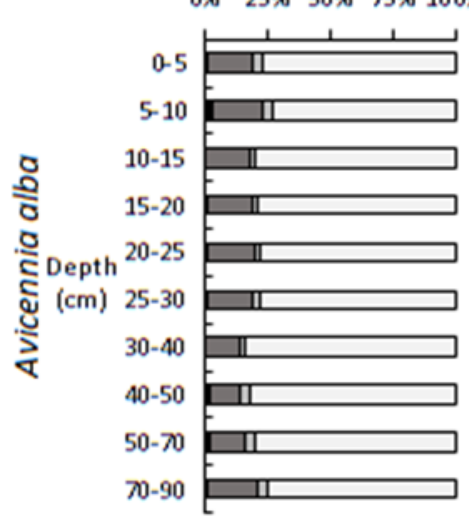

$0 \% \quad 25 \% \quad 50 \% \quad \pi \% 100 \%$

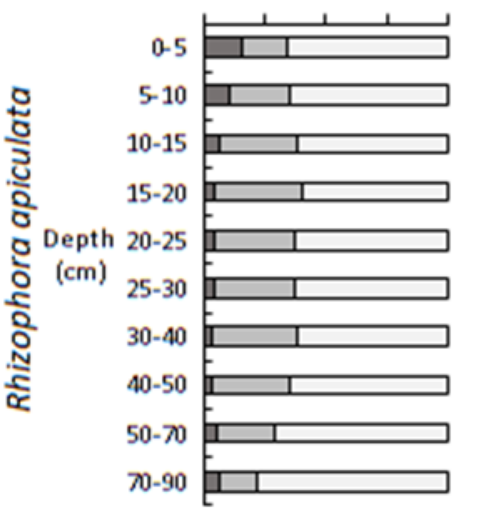

-F1-Exchangeable/carbonate fraction (acid-soluble phases)

$\square$ F2-Oxides fraction (reducible phase)

口F3-Organic fraction (oxidizable phase)

口F4-Residual fraction

$0 \% \quad 25 \% \quad 50 \% \quad \pi \% \quad 100 \%$
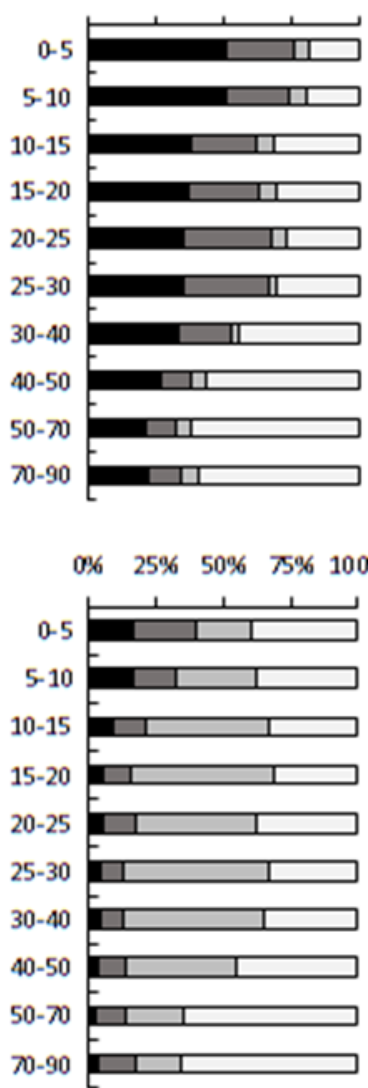

(c) $\mathrm{Ni}$
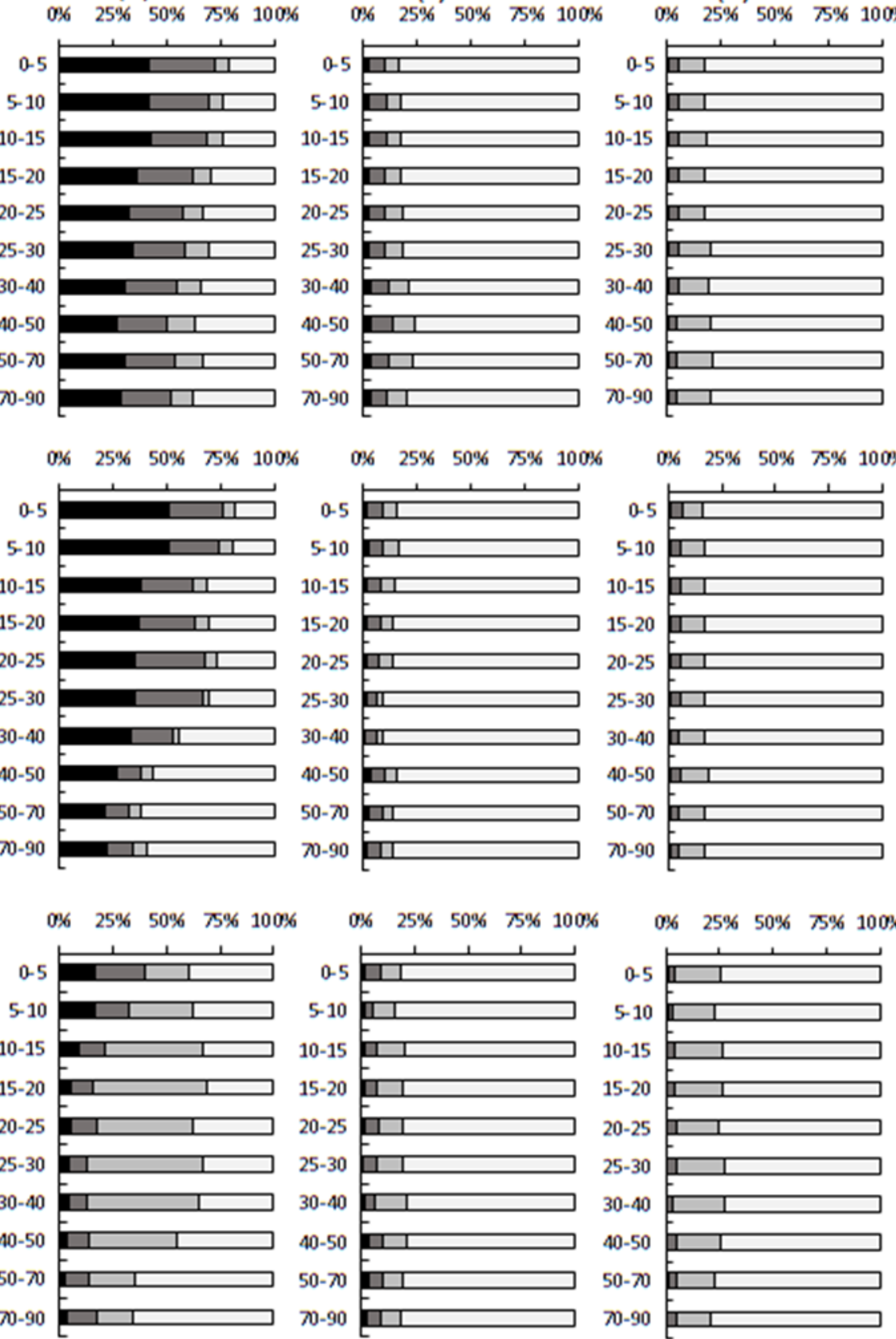
mudflat, the Avicennia stand and the Rhizophora stand in the Can Gio Mangrove (to be continued). 
(e) $\mathrm{Cu}$

0\% $\quad 25 \% \quad 50 \% \quad 75 \% \quad 100 \%$
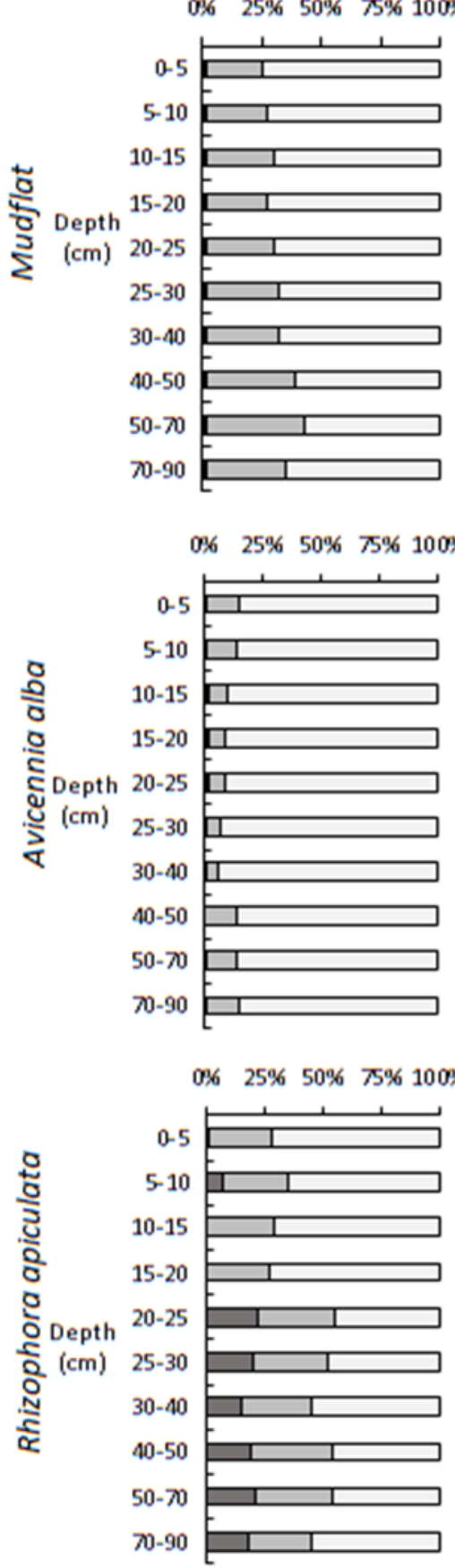

-F1-Exchangeable/carbonate fraction (acid-soluble phases)

aF2-Oxides fraction (reducible phase)

$\square$ F3-Organic fraction (oxidizable phase)

口F4-Residual fraction (f) $\mathrm{Co}$

(g) As
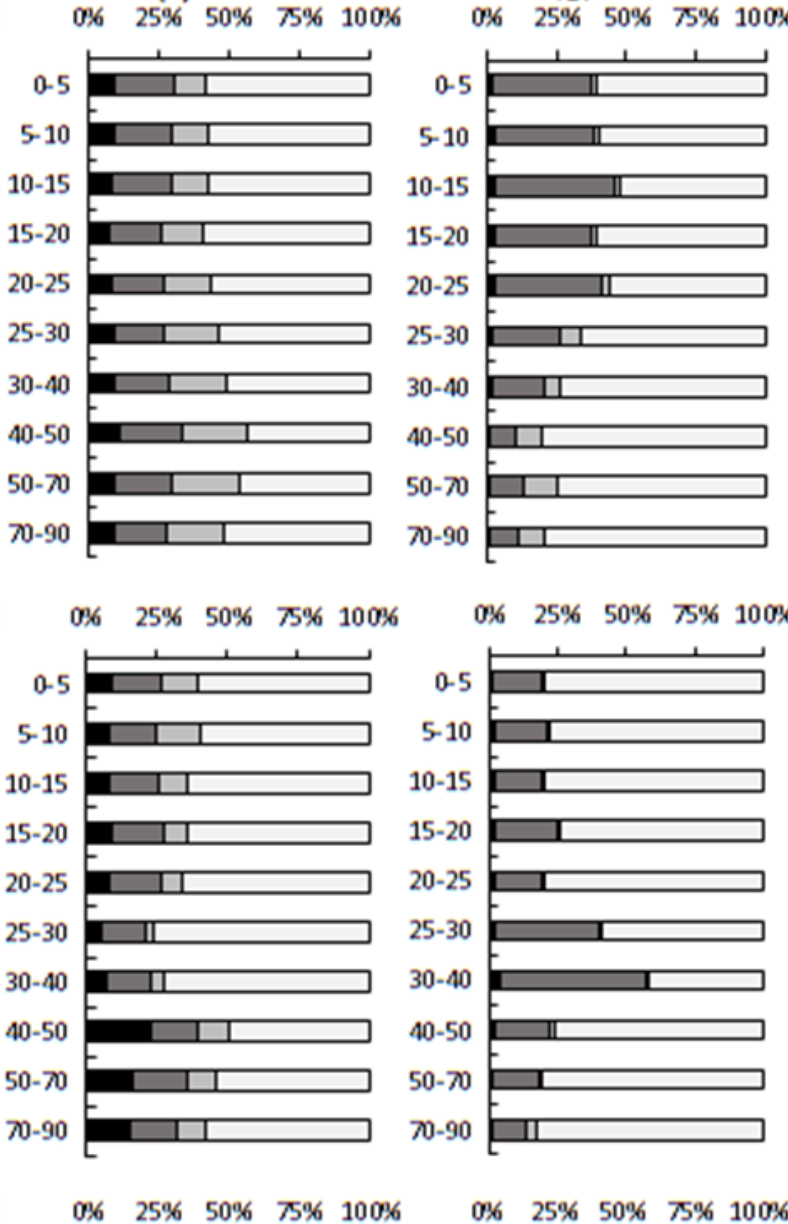

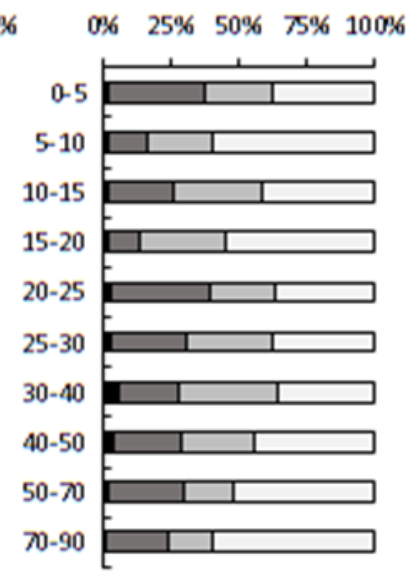

Fig. 4. (Continued)

371 3.5. Dissolved metal concentrations in the core's pore-waters 
Dissolved Fe concentrations $\left(\mathrm{Fe}_{\mathrm{D}}\right)$ in pore-waters presented lower level of concentration in the

373

Rhizophora stand (14 to $3,055 \mu \mathrm{g} \mathrm{L}^{-1}$ ) and the mudflat $\left(1,621\right.$ to $\left.10,303 \mu \mathrm{g} \mathrm{L}^{-1}\right)$ than in the Avicennia stand (333 to $40,771 \mu \mathrm{g} \mathrm{L}^{-1}$ ). The $\mathrm{Fe}_{\mathrm{D}}$ distributions were characterized by decreasing $\mathrm{Fe}_{\mathrm{D}}$ from the surface to $15 \mathrm{~cm}$ depth and then increasing values with depth in the stands (Fig. 5a). Dissolved Mn concentrations $\left(\mathrm{Mn}_{\mathrm{D}}\right)$ presented higher levels in the mudflat (from 6,812 to $15,106 \mu \mathrm{g} \mathrm{L}^{-1}$ ) and in the Avicennia stand (25 to $13,648 \mu \mathrm{g} \mathrm{L}^{-1}$ ) than in the Rhizophora stand (from 542 to $643 \mu \mathrm{g} \mathrm{L}^{-1}$ ) (Fig. 5b). The $\mathrm{Mn}_{\mathrm{D}}$ concentrations decreased from the top to $10 \mathrm{~cm}$ depth (in Avicennia stand) and to $40 \mathrm{~cm}$ depth (in Rhizophora stand) and then increased again with depth.

The dissolved $\mathrm{Ni}\left(\mathrm{Ni}_{\mathrm{D}}\right), \mathrm{Cr}\left(\mathrm{Cr}_{\mathrm{D}}\right)$ and $\mathrm{Cu}\left(\mathrm{Cu}_{\mathrm{D}}\right)$ concentrations in pore-waters presented similar patterns in the three cores (Fig. 5c, 5d and 5e). In the mudflat and the Avicennia stand, $\mathrm{Ni}_{\mathrm{D}}, \mathrm{Cr}_{\mathrm{D}}$ and $\mathrm{Cu}_{\mathrm{D}}$ were stable with depth with increasing concentrations at $30 \mathrm{~cm}$ depth in the mudflat and at $15 \mathrm{~cm}$ depth in the Avicennia stand. In the Rhizophora stand, $\mathrm{Ni}_{\mathrm{D}}, \mathrm{Cr}_{\mathrm{D}}$ and $\mathrm{Cu}_{\mathrm{D}}$ presented higher concentrations with a decreasing pattern from the top to the surface for $\mathrm{Ni}_{\mathrm{D}}$ and $\mathrm{Cu}_{\mathrm{D}}$ and a stable pattern with two peaks at $15 \mathrm{~cm}$ and $30 \mathrm{~cm}$ depth for $\mathrm{Cr}_{\mathrm{D}}$. The dissolved $\mathrm{Co}\left(\mathrm{CoD}_{\mathrm{D}}\right)$ and $\mathrm{As}\left(\mathrm{As}_{\mathrm{D}}\right)$ concentrations in pore-waters (Fig. 5f, $5 \mathrm{~g}$ ) presented a stable vertical distribution with a peak at 30 $\mathrm{cm}$ in the mudflat core while in the Avicennia stand, they presented decreasing concentrations from the top to $10 \mathrm{~cm}$ depth, increasing concentrations until reaching a peak at $30 \mathrm{~cm}$ and $40 \mathrm{~cm}$ depth for $\mathrm{CO}_{\mathrm{D}}$ and $\mathrm{As}_{\mathrm{D}}$ respectively, and then decreasing concentrations towards the bottom. Finally in the Rhizophora stand, $C_{D}$ decreased with depth with a peak at $15 \mathrm{~cm}$ depth while $\mathrm{As}_{\mathrm{D}}$ is stable with two peaks at $25 \mathrm{~cm}$ and $50 \mathrm{~cm}$ depth. 
(a) $\mathrm{Fe}$

$0 \quad 15,00030,00045,000 \quad 0$

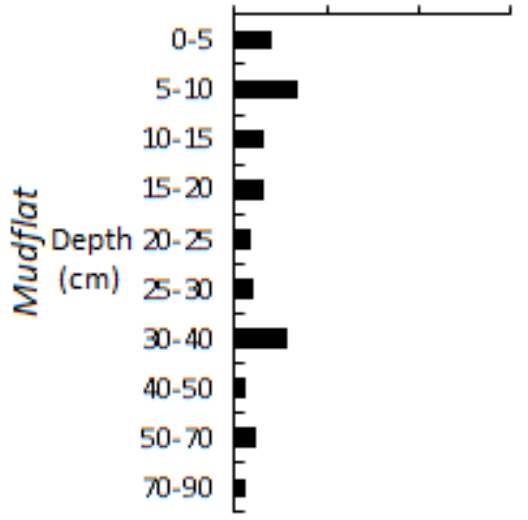

(b) $\mathrm{Mn}$

10,000

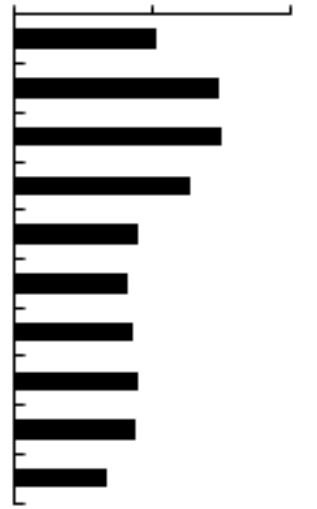

$10,000 \quad 20,000$
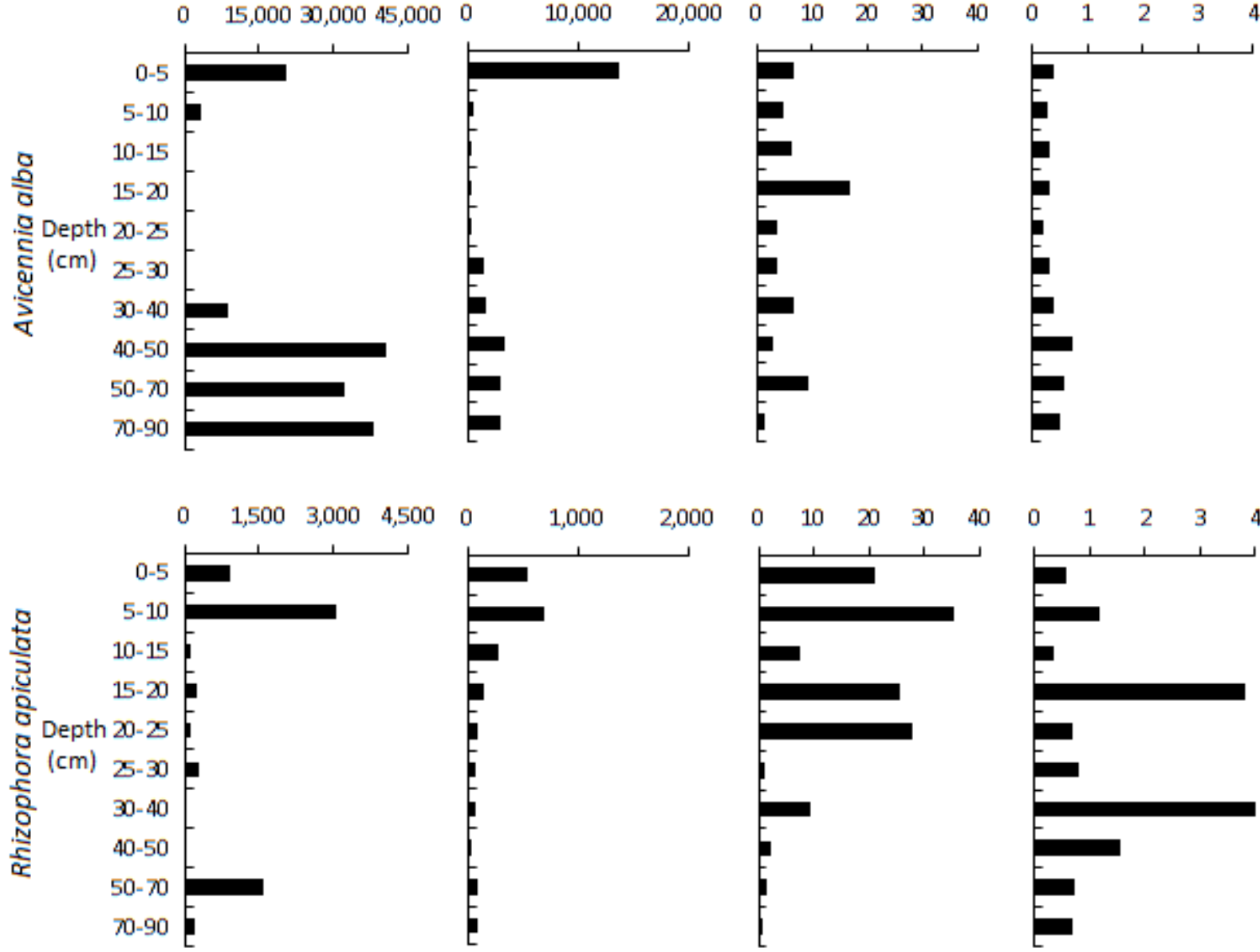

(c) $\mathrm{Ni}$
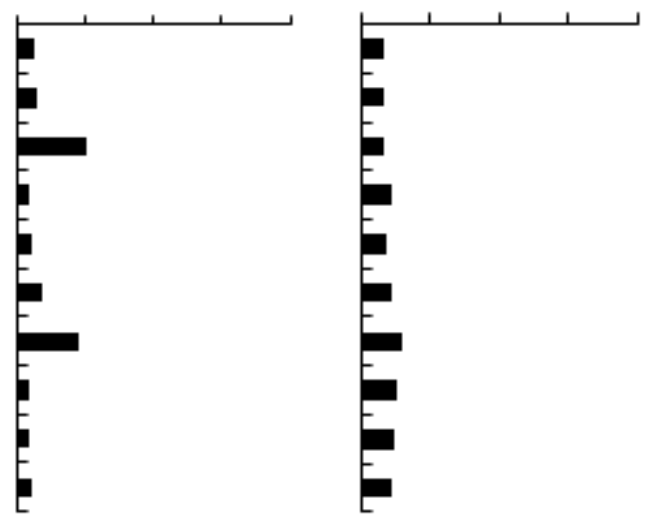

(d) $\mathrm{Cr}$
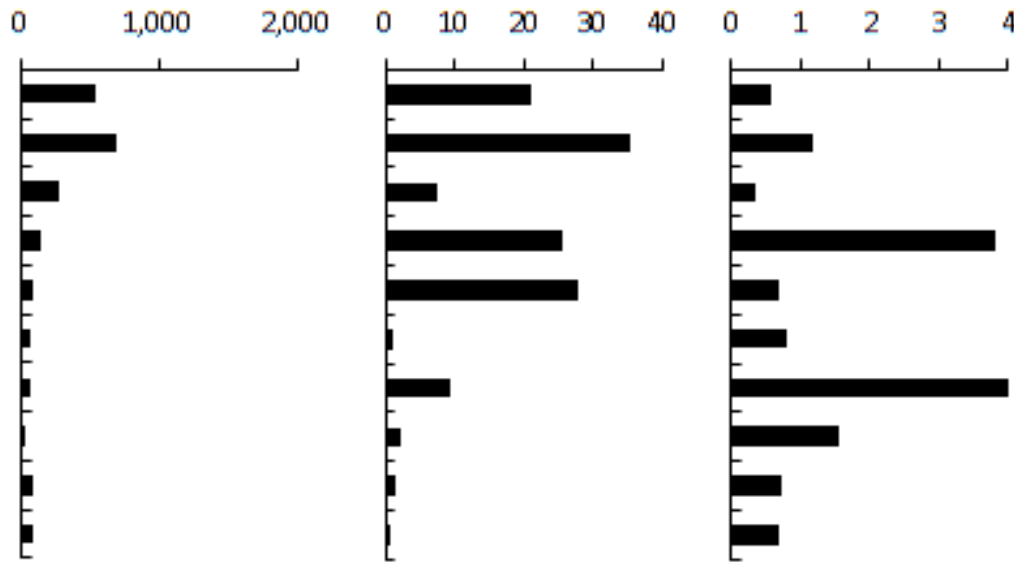

Fig. 5. Depth profile of dissolved metals concentrations $\left(\mu \mathrm{g} \mathrm{L}^{-1}\right)$ in the pore-waters of the mudflat, Avicennia and Rhizophora stands. Asterisks highlight extreme values that could not be shown in the graph even with cut axis (i.e. 
(e) $\mathrm{Cu}$

$\begin{array}{lll}\text { (f) } \mathrm{Co} & \text { (g) As }\end{array}$
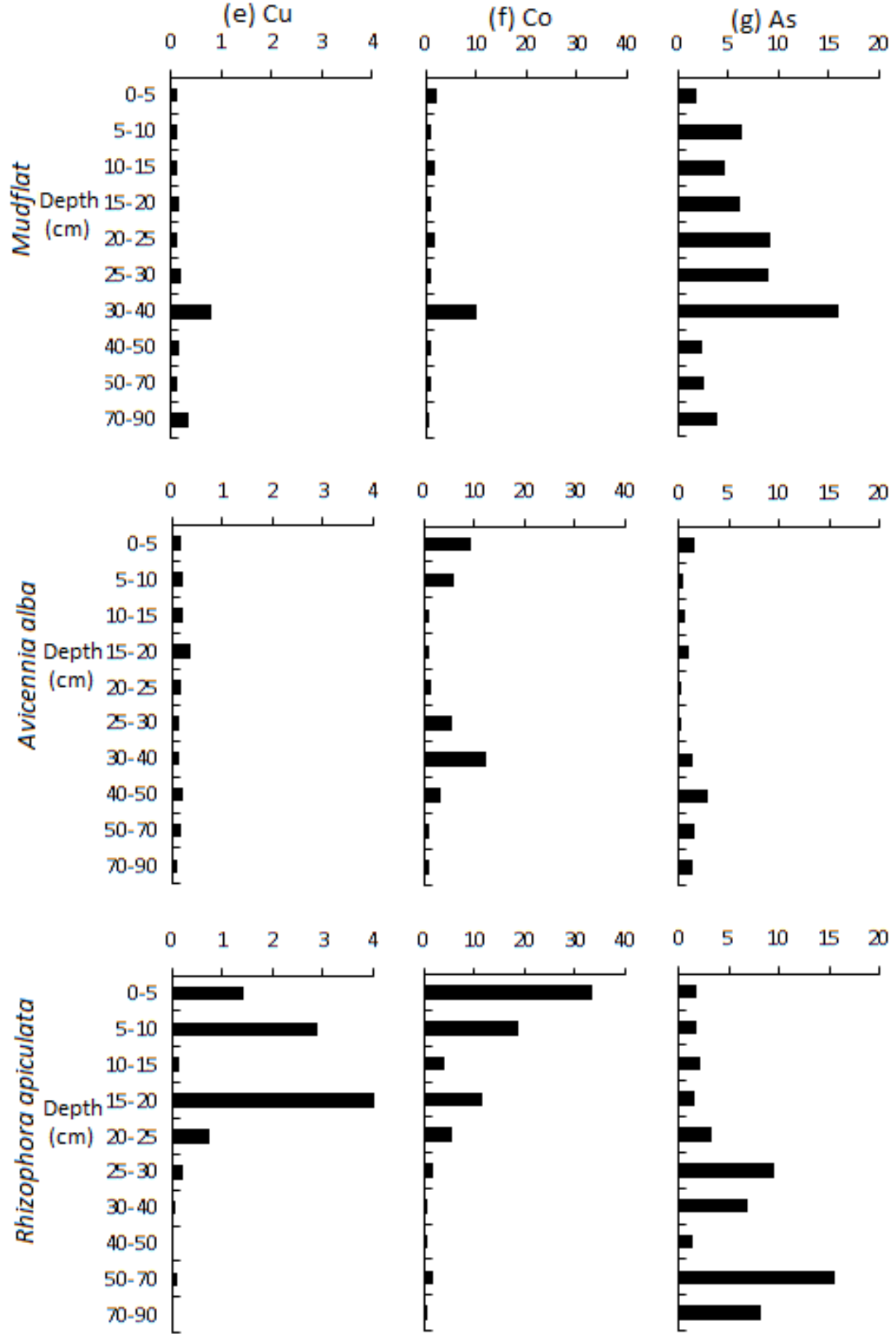

Fig. 5. (Continued)

\section{Discussions}

\subsection{Mangrove sediments characteristics}

Mangrove forests are known to be highly productive ecosystems (Bouillon et al. 2008), storing

huge quantity of carbon in their sediments. Kristensen et al. (2008a) showed that TOC values in mangrove sediments usually range between $0.5 \%$ and $15 \%$, with a median value around $2.2 \%$. In the Can Gio Mangrove, TOC reached up to $4.6 \%$ with increasing values from the tidal creek (the 
mudflat core) to the inner mangrove (the Rhizophora stand core) (Fig. 2). The higher values measured beneath the Rhizophora stand than beneath the Avicennia stand may result from a higher productivity of the first species, including a more developed root system as it was observed in Australia (Alongi et al. 2000) or in New Caledonia (Marchand et al. 2011b). It may also be related to the elevation of the sediment: the Avicennia trees in the Can Gio Mangrove developing at lower elevation than the Rhizophora ones may thus be subject to a more intense tidal export of leaf litter, which limits organic matter accumulation in the sediment. Additionally, the oxygen released by the roots of Avicennia trees may induce more efficient organic matter decomposition (Marchand et al. 2004). Beneath the two mangrove stands, the redox values decreased with depth probably as a result of organic matter decay and the lack of electron acceptors renewal at depth (Otero et al. 2009). In the upper part of the sediments, the suboxic condition $(100<\mathrm{Eh}<260 \mathrm{mV})$ may be explained by biological or physical factors (i.e. length of emersion, crab activity and bioturbation by mangrove roots) (Marchand et al. 2012). The radial cable roots of Avicennia trees can also be important factor inducing higher Eh values than in the Rhizophora stand (Marchand et al. 2004). Whereas the mudflat is flooded almost all the time, the absence of air diffusion into the sediment can result to anoxic condition despite its low organic content. We suggest that more intense organic decomposition and possible sulfide oxidation may cause lower $\mathrm{pH}$ in the Avicennia stand than in the Rhizophora stand and in the mudflat (Marchand et al. 2004). Finally, the upper sediment of every core was characterized by lower salinity values than deeper sediment, which can be related to the period of coring, i.e. the end of the wet season, the rainwater inducing a dilution of the saline pore-waters. The rainwater may also be responsible of an enhanced renewal of electron acceptors, influencing OM diagenesis.

\subsection{Lateritic soil as a main source of trace metal in the mangrove sediments.}

Mean metal concentrations ( $\mathrm{Fe}, \mathrm{Mn}, \mathrm{Ni}, \mathrm{Cr}, \mathrm{Co}, \mathrm{Cu}$ and $\mathrm{As}$ ) in the Can Gio Mangrove sediments (supplementary data, Fig. 3) are in the range of other mangroves around the world (see review papers of Lewis et al. (2011) and Bayen (2012)) but are lower than those measured in mangroves subject to strong anthropogenic pressure as in India (Fernandes and Nayak 2012). Furthermore, 
these metal concentrations were also close to those measured in total suspended matter (TSM) in the Can Gio Mangrove Estuary (Thanh-Nho et al. 2018). These authors stated that TSM acted as main carrier for metals during their transport to the ocean, and that metal distribution changed due to the physical mixing by the seawater and/or organic matter decay processes. Consequently, most metal concentrations in TSM collected in the estuary were lower than upstream, specifically during the monsoon. We suggest that despite being downstream of a developing megacity characterized by low urban wastewater treatments (only $10 \%$, (FAO 2014)), metal accumulation inside the mangrove forest was relatively limited. Thus, we consider that the main source of metals in the Can Gio Mangrove is natural and originates from the rivers' watershed in the Central Highland of Vietnam, composed of lateritic soil originating from the physico-chemical weathering processes of basaltic rocks (Egawa and Ooba 1963) rich in hematite and goethite minerals. This hypothesis may be supported by the high proportion of metals in the residual fraction (Fig. 4) and interrelationships of total metals concentrations in the mudflat, which reflect sediment inputs without the influences of mangrove trees (Table 3).

Table 3. Pearson correlation matrix of total metal concentrations together in the mangrove mudflat. Metal concentrations were expressed in $\mathrm{mg} \mathrm{kg}^{-1}$.

\begin{tabular}{|c|c|c|c|c|c|c|c|}
\hline & $\mathrm{Fe}$ & $\mathrm{Mn}$ & $\mathrm{Ni}$ & $\mathrm{Cr}$ & $\mathrm{Cu}$ & Co & As \\
\hline $\mathrm{Fe}$ & 1 & & & & & & \\
\hline $\mathrm{Mn}$ & -.476 & 1 & & & & & \\
\hline $\mathrm{Ni}$ & $.875^{* *}$ & -.483 & 1 & & & & \\
\hline $\mathrm{Cr}$ & .538 & .155 & .544 & 1 & & & \\
\hline $\mathrm{Cu}$ & $.842^{* *}$ & -.495 & $.854^{* *}$ & $.674^{*}$ & 1 & & \\
\hline Co & $.831^{* *}$ & $-.673^{*}$ & $.936^{* *}$ & .300 & $.828^{* *}$ & 1 & \\
\hline As & .537 & -.447 & .424 & .271 & $.757^{*}$ & .562 & 1 \\
\hline
\end{tabular}

**. Correlation is significant at the 0.01 level (2-tailed).

*. Correlation is significant at the 0.05 level (2-tailed).

\subsection{Trace metal geochemistry in the sediment cores.}

\subsubsection{Redox sensitive elements ( $F$ e and $M n$ )}

Iron geochemistry 

the transfer of these Fe-oxyhydroxides towards the estuary and then their deposition in the mangrove. In the main channel of the Can Gio Estuary, we measured iron concentration up to 55,302 $\mathrm{mg} \mathrm{kg}^{-1}$ during the monsoon (Thanh-Nho et al. 2018), which comfort our hypothesis. However, in mangrove sediments, the oxide fraction was not the dominant one. This may be attributed first to the limitation of the selective extraction method offered by Tessier et al. (1979), which is inefficient to extract iron from highly crystallized oxides and oxyhydroxides, like iron crystalized forms e.g. ferrihydrite or lepidocrocite (Ferreira et al. 2007), and which may explain the dominance of the residual fraction. In the studied mangrove sediments, Fe partitioning in sediments and $\mathrm{Fe}_{\mathrm{D}}$ concentrations varied with depth and between stands (Fig. $4 \mathrm{a}$ and 5a), which could result from the different redox conditions and driven by $\mathrm{OM}$ decomposition, bioturbation or root system activities. Iron partitioning beneath the Avicennia stand and the mudflat was similar, but the one beneath the Rhizophora stand was different and showed higher Fe concentrations in the oxidizable fraction but lower dissolved iron concentrations and lower Fe concentrations in residual, reducible and exchangeable/carbonate bound fractions. Thus, as Fe can form stable chelate complexes with organic matter (Thamdrup 2000), the increase of TOC in anoxic condition which were observed toward the landside of the mangrove could be responsible of the increasing Fe binding with organic phases in the mangrove sediment (Chakraborty et al. 2016). This phenomenon could be affirmed by negative correlation of Fe proportion in the oxidizable fraction with those in the reducible and the residual phases $(r=-0.67$ and -0.85 , Fig. $6 \mathrm{a}$ and $6 \mathrm{~b}$ respectively). We also suggest that $\mathrm{Fe}-$ oxihydroxydes originating from the lateritic soil of the watersheds were dissolved during diagenetic processes because of increased organic content (Froelich et al. 1979) and that the dissolved iron concentrations of $\mathrm{Fe}$ in the residual fraction at depth in the Rhizophora stand. Unfortunately, we were not able to measure neither total sulfur (TS) nor sulphide in the studied mangrove sediments. However, it is known that mangrove sediments are characterized by high rate of sulfate reduction 
(Kristensen 2008b) and elevated TS content and pyrite are commonly observed in mangrove forest, especially at depth (Marchand et al. 2011a, Marchand et al. 2006). Eventually and in addition to these reduction processes, the re-oxidation of aqueous Fe(II) and pyrite could lead to the formation of poorly ordered ferrihydrite, lepidocrocite (c-FeOOH) and likely goethite (Noël et al. 2014) in the upper suboxic sediments, but cannot be confirmed with the selective extraction used.

\section{Manganese geochemistry}

Manganese is known as a highly redox sensitive element (Lacerda et al. 1999). Like for Fe, the presence of $\mathrm{Mn}_{\mathrm{D}}$ in the pore-waters may result from the reductive dissolution of Mn-oxyhydroxides during the diagenetic processes (Froelich et al. 1979). This process can be responsible for the presence of high $\mathrm{Mn}_{\mathrm{D}}$ concentrations in pore-waters, reaching more than $10,000 \mu \mathrm{g} \mathrm{L}^{-1}$ in the mudflat (Fig. 5b). The lower Mn $\mathrm{n}_{\mathrm{D}}$ observed in the Avicennia and Rhizophora stands than in the mudflat sediments may be related (i) to the loss of $\mathrm{Mn}_{\mathrm{D}}$ by tidal drainage (Lacerda et al. 1999), $\mathrm{Mn}_{\mathrm{D}}$ release from mangrove pore-waters being as a significant component of $\mathrm{Mn}$ oceanic budget (Holloway et al. 2016), (ii) to an uptake by mangrove plants (Wang et al. 2002), or iii) to more intense reprecipitation of $\mathrm{Mn}$ with other bearing phases after oxyhydroxides dissolution. We suggest that those processes were more pronounced for the Rhizophora stand, with 5-fold lower in mean concentration of dissolved Mn than those in the Avicennia stand (Fig. 5b). However and conversely to $\mathrm{Fe}$, the dominant $\mathrm{Mn}$ fraction was the carbonate one in the two mangrove stands. Unlike $\mathrm{Fe}, \mathrm{Mn}$ sulphides are unstable $\left(\mathrm{pK}_{\mathrm{sp}}=1.3\right)$ and the precipitation of $\mathrm{Mn}$ as sulphides may be severely limited by the presence of dissolved $\mathrm{Fe}^{2+}$ and carbonate. Because of similar ionic radii, $\mathrm{Ca}$ can be substituted by Mn in carbonate minerals (Costa-Boddeker et al. 2017, Rath et al. 2009). Previous studies, e.g. concerning mangrove sediments in the West coast of India (Noronha-D'Mello et al. 2015) or in Brazilia (Otero et al. 2009), reported that a considerable quantity of the free manganese was associated with carbonate (i.e. up to $2.5 \mu \mathrm{mol} \mathrm{g}^{-1}$ ). Marchand et al. (2008) suggested that the decomposition of organic matter in mangrove sediments leads to the production of dissolved inorganic carbon (DIC) that can migrate at depth, where carbonate minerals can precipitate because of the marked anoxic conditions that prevail there compared to the upper 
suboxic layers. This carbonate precipitation can be a sink for some elements, including Mn. In the Rhizophora stand, within the organic rich-layers, oxidizable fraction was the predominant one for Mn, suggesting that Mn was adsorbed onto OM (Thamdrup 2000). This hypothesis may be supported by negative correlation between Mn concentrations in the oxidizable fraction with those in the reducible and in the residual phase (i.e. $r=-0.69$ and -0.79 , Fig. $6 \mathrm{c}$ and $6 \mathrm{~d}$ respectively).

\subsubsection{Geochemistry of $\mathrm{Cu}, \mathrm{Ni}, \mathrm{Cr}, \mathrm{Co}$, and $\mathrm{As}$}

\section{Copper geochemistry}

Copper may be released in pore-waters upon OM decay processes and/or reductive dissolution of Fe-Mn oxyhydroxides under suboxic conditions. $\mathrm{Cu}$ is a chalcophile element, being easily chemisorbed on or incorporated in several minerals such as chalcopyrite $\left(\mathrm{CuFeS}_{2}\right)$, covellite $(\mathrm{CuS})$ and malachite $\mathrm{Cu}_{2} \mathrm{CO}_{3}(\mathrm{OH})_{2}$ (Pickering 1986). However, chalcopyrite and malachite are not stable under acidic conditions, especially at $\mathrm{pH}$ values ranging from 5 to 6 . Therefore, the high $\mathrm{Cu}$ concentrations in the residual fraction beneath the Avicennia stand (where $\mathrm{pH}$ values < 6), compared to the mudflat and the Rhizophora stand, may result from the intense precipitation of $\mathrm{Cu}$ as sulphides, mainly $\mathrm{CuS}$ and/or $\mathrm{Cu}_{2} \mathrm{~S}$ (Fernandes 1997, Morse and Luther 1999). In the Can Gio Mangrove sediment, the negative correlation observed between the organic fraction and the residual one whatever the sites (i.e. $\mathrm{r}=-0.89$, Fig. 6 e), evidenced that the control of organic matter on $\mathrm{Cu}$ partitioning (Chakraborty et al. 2015, Marchand et al. 2016, Silva et al. 2014) subsequently induces the opposite trend of $\mathrm{Cu}$ concentrations in the other fractions (i.e. exchangeable/carbonate and oxides bound, Fig. 4e). We note that beneath the Rhizophora stand, Cu concentrations in the organic fraction were higher than in the two other sites (Fig. 4e). Interestingly, the $\mathrm{Cu}_{\mathrm{D}}$ in the three cores are in the same range than those measured in the Can Gio Mangrove Estuary surface water (ThanhNho et al. 2018). Cu is known to be an essential element for plant growth (Yruela 2009) and to bioaccumulate up to a bioconcentration factors of 9 in leaves and 5 in roots of mangrove trees (MacFarlane et al. 2003, Usman et al. 2013). Therefore, its low contents in pore-waters in addition to its precipitation with $\mathrm{OM}$ and sulphides may be related to its uptake by the mangroves root systems (Chakraborty et al. 2014, MacFarlane and Burchett 2002). However, some peaks of 
533

534

535

536

537

538

539

540

541

542

543

544

545

546

547

548

549

550

551

552

553

554

555

556

557

558

559

increasing $\mathrm{Cu}_{\mathrm{D}}$ are observed at $5 \mathrm{~cm}, 10 \mathrm{~cm}$ and $20 \mathrm{~cm}$ depth $\left(1.4 \mu \mathrm{g} \mathrm{L}^{-1} 2.9 \mu \mathrm{g} \mathrm{L}^{-1}\right.$ and $13.8 \mu \mathrm{g} \mathrm{L}$ ${ }^{1}$, respectively) in the Rhizophora stand (Fig. 5e), which may be attributed to a limited reprecipitation with oxides-bearing and supported by the $\mathrm{Cu}$ decreasing in the oxides fraction at these layers (Fig. 4e).

\section{Nickel and Chromium geochemistry}

The high proportions of $\mathrm{Ni}$ and $\mathrm{Cr}$ in the residual fractions from the mudflat to the inner mangrove stands may be attributed to more intense precipitation of Ni pyrite and/or Ni sulphide (Clark et al. 1998, Noël et al. 2015), reflecting their natural sources linked to iron minerals. This hypothesis could be supported by positive correlation between $\mathrm{Ni}, \mathrm{Cr}$ and $\mathrm{Fe}$ proportions in the residual fractions respectively $(r=0.65$ and 0.87 , Fig. $6 f$ and $6 g$ ). In the Can Gio Mangrove, the OM increase in the Rhizophora stand's sediment implies intense diagenetic processes which could lead to the formation of organocomplexes with dissolved $\mathrm{Ni}$ and $\mathrm{Cr}$ at the adequate $\mathrm{pH}$ (i.e. $3.4 \%$ of mean TOC concentrations and $\mathrm{pH}$ ranging from 6.4 to 6.8). Doig and Liber (2006) demonstrated that the organonickel complexes may be formed at $\mathrm{pH} 6$ to 8 , which may explain the higher concentrations of $\mathrm{Ni}$ in the organic fraction beneath Rhizophora than beneath the two other stands (i.e. $11.4 \%$ in the Rhizophora stand vs. $5.4 \%$ in the Avicennia stand and $8.2 \%$ in the mudflat, Fig. 4c). In fact, the variation of organic matter with depth in the Rhizophora stand induces the modification of Ni partitioning between bearing phases (e.g. a negative correlation was observed between Ni proportion in F3 and F4, $\mathrm{r}=-0.6$, Fig. $6 \mathrm{~h}$ ). Similar phenomenon was observed for $\mathrm{Cr}$ partitioning, being supported by a negative correlation between $\mathrm{Cr}$ proportion in F3 and F4 beneath the Rhizophora stand, $\mathrm{r}=-0.96$, Fig. 6i) like demonstrated in New Caledonia (Marchand et al. 2012). Lacerda et al. (1991) also observed in a Brazilian mangrove that $\mathrm{Cr}$ was immobilized in sediment as organochromium complexes.

Cobalt and Arsenic geochemistry

Conversely to $\mathrm{Cu}, \mathrm{Ni}$, and $\mathrm{Cr}$, the concentrations of $\mathrm{Co}$ and $\mathrm{As}$ in the exchangeable/carbonate bound fraction were elevated, reaching up to $23 \%$ and $5.4 \%$ respectively. As explained earlier for Mn partitioning and the presence of Mn-carbonates, we suggest that the decomposition of organic 
matter can lead to DIC production, which can precipitate in specific redox-pH values, incorporating some elements, mainly $\mathrm{Mn}$ but also $\mathrm{Co}$ and As. Co and $\mathrm{Mn}$ proportions in the exchangeable/carbonate fraction showed the opposite distribution patterns with depth whatever the sites (Fig. 4f) which implies considerable competition of dissolved $\mathrm{Mn}$ on the formation of carbonate cobalt (i.e. negative correlation observed in the mudflat, $r=-0.50$, Fig. $6 j$; in the Avicennia stand, $\mathrm{r}=-0.64$, Fig. 6k ). In fact, Co (III) can be substituted to $\mathrm{Mn}$ in $\mathrm{Mn}$ (III/IV) oxides because of their similar ionic radii, (Manceau et al. 1997). This process can occur in the same EhpH space in which Mn (II) oxidation occurs (Murray and Dillard 1979). However, it was not the case for Co behavior in the Rhizophora stand which may be attributed to the influence of OM. As a consequence, a negative correlation between the Co proportion in the residual fraction and the organic one was observed $(r=-0.83$, Fig. 61$)$, which evidenced one more time the key role of organic matter in trace metal partitioning in mangrove sediments. Beneath the Avicennia stand, Co concentrations in the organic fraction were the lowest of the 3 stands despite similar range of TOC in the mudflat, which may result the precipitation of dissolved Co into sulphides forms (Charriau et al. 2011). In the case of As, we suggest that the increasing concentrations of As in the residual fraction with depth in every sites may result from the incorporation of As into pyrite. In fact, the most common iron sulphide minerals have strong affinity for, and can incorporate large amounts of arsenic in its structure, up to $10 \mathrm{wt} \%$ (Abraitis et al. 2004, Qiu et al. 2017). Noël et al. (2014) stated that pyrite was the predominant Fe bearing phase at depth in mangrove sediments. Notably, dissolved As concentrations were relatively high in the mudflat and at depth in the Rhizophora stand, reaching almost $20 \mu \mathrm{g} \mathrm{L}^{-1}$ (Fig. 5g). We suggest that the presence of As in pore-waters results from the reductive dissolution of As bound to oxides under suboxic/anoxic conditions (Masscheleyn et al. 1991, Nickson et al. 2000). Recent studies also supported that the reduction of Fe-oxyhydroxides was a cause of As release into ground water in Bangladesh (Anawar et al. 2003, Zheng et al. 2004). 

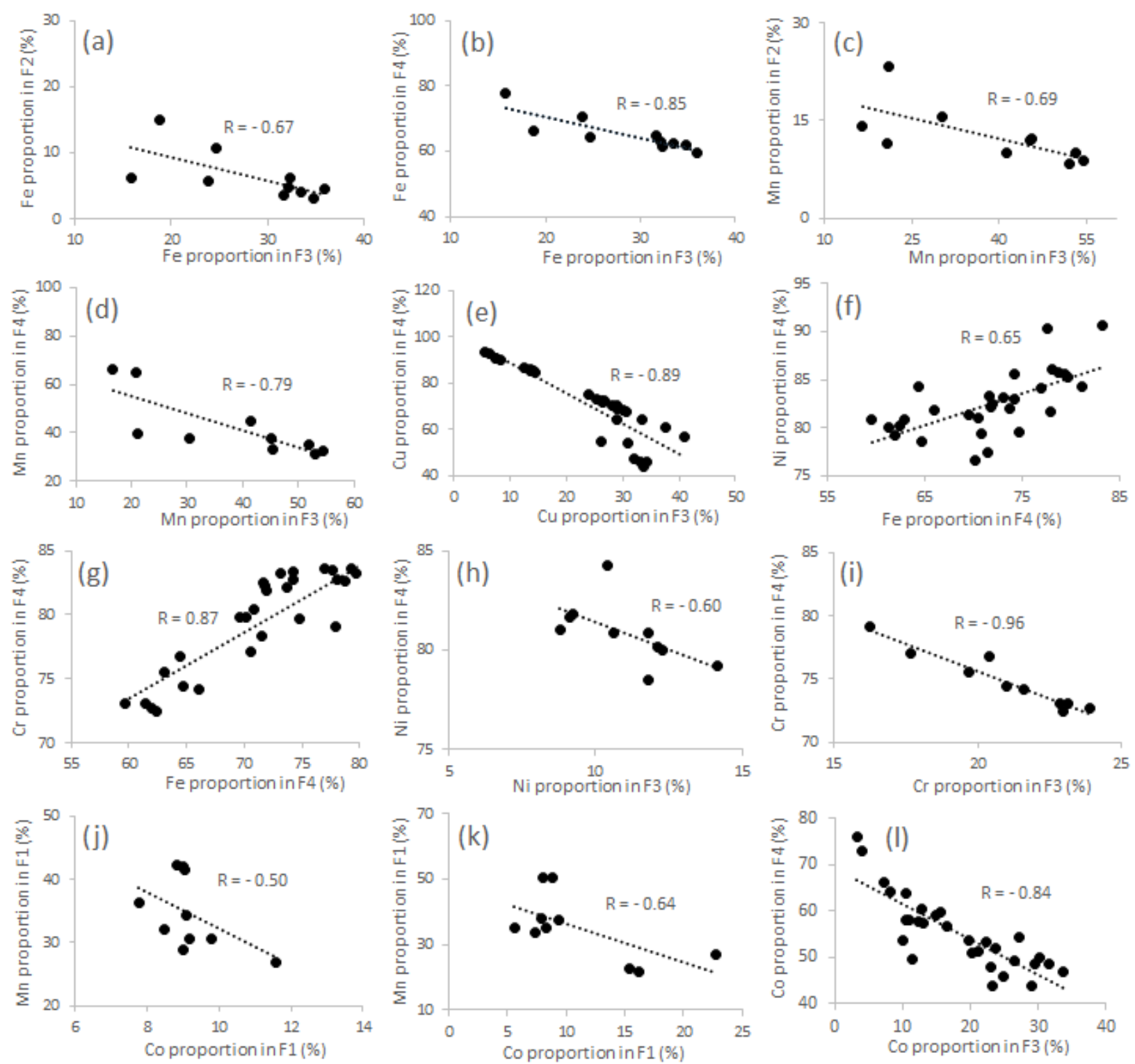

Fig. 6. Interrelationships of metals proportions in the different fractions of the sediment cores in Can Gio Mangrove:

( $a$ and b) Fe proportions beneath the Rhizophora stand; ( $c$ and d) Mn proportions beneath the Rhizophora stand; (e) data of Cu proportion beneath mangrove stands and mudflat; ( $f$ and $g$ ) Fe proportion in $\mathrm{F} 4$ correlated to Ni and $\mathrm{Cr}$ proportion in $F 4$ of all sites from the mudflat to inner the Avicennia and Rhizophora stands, respectively; ( $h$ and $i) N i$ and Cr proportions beneath the Rhizophora stand; ( $j$ and $k$ ) Co and Mn proportions selected from the mudflat and the Avicennia stand, respectively; (l) Co proportions from all cores.

\subsection{Assessment of metal stocks and ecological potential risks}

The estimated metal stocks in the upper $50 \mathrm{~cm}$ sediment were lower in the Rhizophora stand compared to the Avicennia one and the mudflat and could be related to two processes. Firstly, the increase organic matter content in the sediment could induce a decrease in the bulk density of the sediments $\left(0.55 \mathrm{~g} \mathrm{~cm}^{-3}\right.$ in the Rhizophora vs. $0.61 \mathrm{~g} \mathrm{~cm}^{-3}$ in the Avicennia and $0.64 \mathrm{~g} \mathrm{~cm}^{-3}$ in the 
mud flat). Secondly, it may be related to a more reactive substrate like described in the previous discussions, which can induce the dissolution of some bearing phases and the export of dissolved metals through pore-water seepage, or the uptake of dissolved metals by mangrove plants. Compared to mangrove of New Caledonia (Marchand et al. 2016), the estimated metal stocks of the Can Gio Mangrove sediments were lower confirming the moderate metal inputs in this system. The bioavailability and potential toxicity of metals in the different geochemical fractions are expected to decrease in the following order: exchangeable/carbonate fraction $>$ oxides fraction > organic fraction > residual fraction (Ma and Rao 1997). To assess the metal availability and associated potential ecological risks of the Can Gio Mangrove sediments, we used the Risk Assessment Code - RAC (Perin et al. 1985) and guideline (Benson et al. 2017, Passos et al. 2010) (Fig. 7).

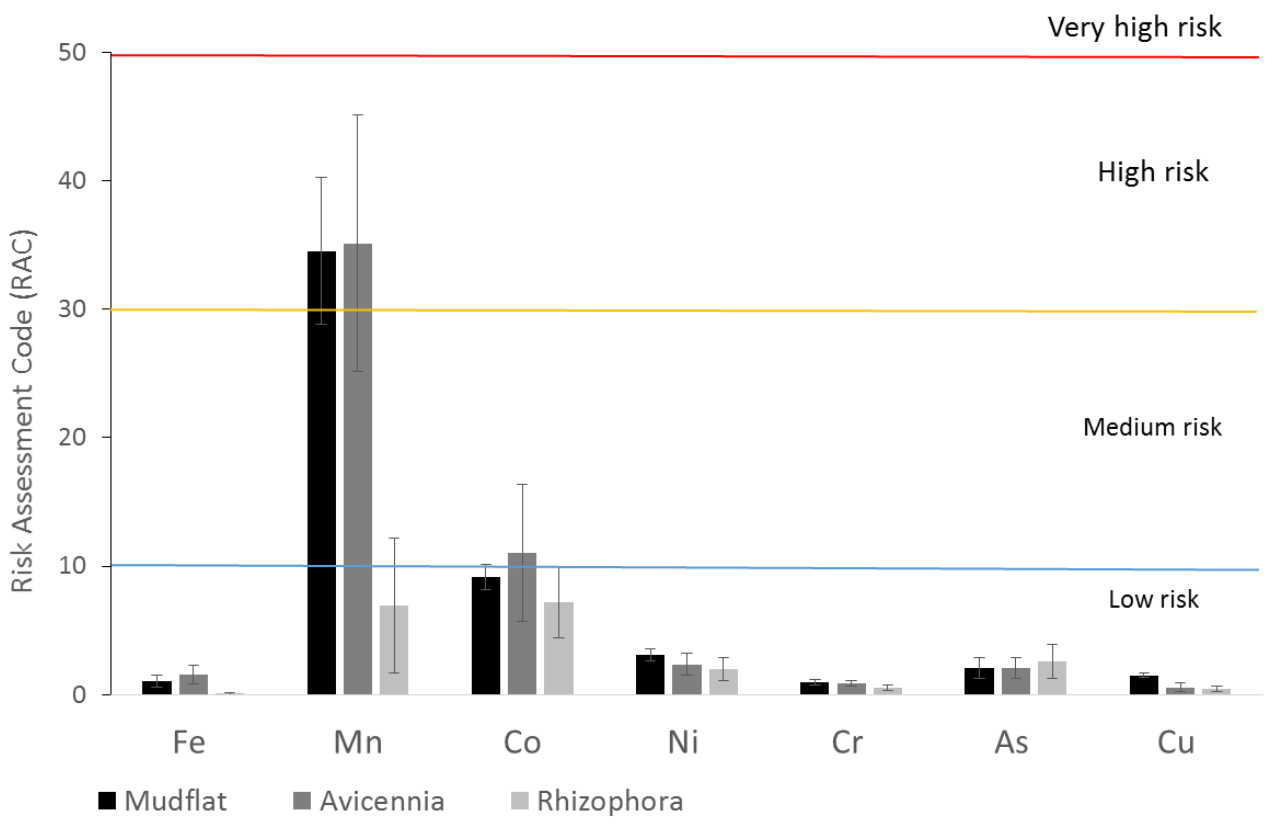

Fig. 7. Risk Assessment Code of metals in the sediment cores of the mudflat, the Avicennia stand and the Rhizophora stand in the Can Gio Mangrove.

The RAC is evaluated based on the percentage of metal concentrations that is representative in the bioavailable fraction (exchangeable/carbonate bound) to the total trace metal concentrations. According to the RAC guideline, metal with less than $1 \%$ of exchangeable/carbonate fraction would be at no risk to the environment while higher ratio suggest: $1 \%$ to $10 \%$ : low risk; $11 \%$ to $30 \%$ : medium risk; $31 \%$ to $50 \%$ : high risk and $>50 \%$ : very high risk. Consequently, in the Can 
Gio Mangrove sediments, only Mn presented a high risk in the mudflat and in the Avicennia stand (i.e. RAC > 33) and a low risk in the Rhizophora stand (i.e. RAC < 7). We note that in plants, Mn excess can damage the photosynthesis apparatus (Millaleo et al. 2010) and thus the plants productivity (Nguyen et al. 2018). Arsenic presented a low risk but its high dissolved concentrations in pore-waters, reaching up to $\sim 20 \mu \mathrm{g} \mathrm{L}^{-1}$, may potentially be an additional ecological risk to organisms. $\mathrm{Ni}, \mathrm{Co}, \mathrm{Fe}$, and $\mathrm{Cu}$ showed low risks to the ecosystem while $\mathrm{Cr}$ was in the no risk category whatever the sites. Along the mangrove, the RAC was lower in the Rhizophora stand than in the Avicennia stand and the mudflat, which may result from the competition of organometallic complexation (see earlier discussion), reflecting the important role of organic matter in scavenging metals in mangrove sediments. Eventually, as a result of mangrove conversion for agriculture and/or aquaculture (i.e. salt production and shrimp farming, etc.), these sediments may be subject to an oxidation resulting in enhanced OM decomposition (Grellier et al. 2017), sulphide oxidation, and thus sediments acidification. Noël et al. (2017) showed that increasing anthropogenic pressure on coastal areas altered the redox state of mangrove sediments from reducing condition to oxidizing condition, affecting the stability of Ni-accumulating Fe-sulfides and releasing significant dissolved metals at the redox boundary. Consequently, metals which were associated with OM and sulphides will be released in pore-waters, but also those associated with the exchangeable/carbonate bound due to the acidification, conducting all metals to be potentially at high ecological risks in the Can Gio Mangrove sediments.

\section{Conclusions}

The Can Gio Mangrove sediments did not present high metals concentrations. Their contents, close to those of the crust, associated with their high proportion in residual fractions suggested that studied metals originated from the lateritic soils of the Sai Gon and Dong Nai River watersheds. These metals were deposited mainly as Fe-Mn oxyhydroxides in the sediment, which were subsequently dissolved by bacteria in suboxic to anoxic conditions during diagenetic processes, releasing them in pore-waters. The $\mathrm{OM}$ enrichment in the sediments from the mudflat to the Rhizophora stand played a key role in metals partitioning, either because its decay modifies the 
redox conditions (inducing oxyhydroxides dissolution and sulphides precipitation) or because of

the formation of organometallic compounds. Most metals presented low ecological risks to the mangrove ecosystem except Mn, and possibly As due to its elevated dissolved concentrations. We would like to underscore that any anthropogenic perturbation in the redox state of those mangrove sediments may result in a release of metal contents in the adjacent ecosystems i.e. mangrove uptake or export to surface water. We suggest that a further detailed investigation on dissolved metal transfer and their accumulation into mangrove biota should be carried out to get a better understanding of metal dynamic in the Can Gio Mangrove ecosystem.

\section{Acknowledgements}

The authors would like to thank the students Nguyen Ngoc Hon and Nguyen Truong Giang for their help during sampling. This research is funded by Vietnam National University Ho Chi Minh City (VNU-HCM) under grand number C2016-18-07.

\section{References}

Abraitis P., Pattrick R. and Vaughan D. (2004). Variations in the compositional, textural and electrical properties of natural pyrite: a review. International Journal of Mineral Processing 74(1-4), 41-59.

Alongi D., Tirendi F. and Clough B. (2000). Below-ground decomposition of organic matter in forests of the mangroves Rhizophorastylosa and Avicenniamarina along the arid coast of Western Australia. Aquatic Botany 68(2), 97-122.

Anawar H. M., Akai J., Komaki K., Terao H., Yoshioka T., Ishizuka T., Safiullah S. and Kato K. (2003). Geochemical occurrence of arsenic in groundwater of Bangladesh: sources and mobilization processes. Journal of Geochemical Exploration 77(2-3), 109-131.

Babut M., Mourier B., Desmet M., Simonnet-Laprade C., Labadie P., Budzinski H., De Alencastro L. F., Tu T. A., Strady E. and Gratiot N. (2019). Where has the pollution gone? A survey of organic contaminants in Ho Chi Minh city / Saigon River (Vietnam) bed sediments. Chemosphere 217, 261-269.

Bayen S. (2012). Occurrence, bioavailability and toxic effects of trace metals and organic contaminants in mangrove ecosystems: a review. Environment International 48, 84-101.

Benson N. U., Udosen E. D., Essien J. P., Anake W. U., Adedapo A. E., Akintokun O. A., Fred-Ahmadu O. H. and Olajire A. A. (2017). Geochemical fractionation and ecological risks assessment of benthic sediment-bound heavy metals from coastal ecosystems off the Equatorial Atlantic Ocean. International Journal of Sediment Research 32(3), 410-420.

Blasco F., Aizpuru M. and Gers C. (2001). Depletion of the mangroves of Continental Asia. Wetlands Ecology and Management 9, 245-256.

Bouillon S., Borges A. V., Castañeda-Moya E., Diele K., Dittmar T., Duke N. C., Kristensen E., Lee S. Y., Marchand C. and Middelburg J. J. (2008). Mangrove production and carbon sinks: a revision of global budget estimates. Global Biogeochemical Cycles 22(2).

Chakraborty P., Chakraborty S., Jayachandran S., Madan R., Sarkar A., Linsy P. and Nath B. N. (2016). Effects of bottom water dissolved oxygen variability on copper and lead fractionation in the sediments across 
the oxygen minimum zone, western continental margin of India. Science of The Total Environment 566, 1052-1061.

Chakraborty P., Chakraborty S., Ramteke D. and Chennuri K. (2014). Kinetic speciation and bioavailability of copper and nickel in mangrove sediments. Marine Pollution Bulletin 88(1-2), 224-230.

Chakraborty P., Ramteke D. and Chakraborty S. (2015). Geochemical partitioning of Cu and Ni in mangrove sediments: relationships with their bioavailability. Marine Pollution Bulletin 93(1-2), 194-201.

Charriau A., Lesven L., Gao Y., Leermakers M., Baeyens W., Ouddane B. and Billon G. (2011). Trace metal behaviour in riverine sediments: Role of organic matter and sulfides. Applied Geochemistry 26(1), 8090.

Clark M. W., McConchie D., Lewis D. W. and Saenger P. (1998). Redox stratification and heavy metal partitioning in Avicennia-dominated mangrove sediments: a geochemical model. Chemical Geology 149(3-4), 147-171.

Cormier-Salem M.-C., Van Trai N., Burgos A., Durand J.-D., Bettarel Y., Klein J., Duc Huy H. and Panfili J. (2017). The mangrove's contribution to people: Interdisciplinary pilot study of the Can Gio Mangrove Biosphere Reserve in Viet Nam. Comptes Rendus Geoscience 349(6-7), 341-350.

Costa-Boddeker S., Hoelzmann P., Thuyen L. X., Huy H. D., Nguyen H. A., Richter O. and Schwalb A. (2017). Ecological risk assessment of a coastal zone in Southern Vietnam: Spatial distribution and content of heavy metals in water and surface sediments of the Thi Vai Estuary and Can Gio Mangrove Forest. Marine Pollution Bulletin 114(2), 1141-1151.

De Wolf H. and Rashid R. (2008). Heavy metal accumulation in Littoraria scabra along polluted and pristine mangrove areas of Tanzania. Environmental Pollution 152(3), 636-643.

Dent D. (1986). Acid sulphate soils: a baseline for research and development, ILRI.

Doig L. E. and Liber K. (2006). Nickel partitioning in formulated and natural freshwater sediments. Chemosphere 62(6), 968-979.

Duke N. C., Meynecke J.-O., Dittmann S., Ellison A. M., Anger K., Berger U., Cannicci S., Diele K., Ewel K. C. and Field C. D. (2007). A world without mangroves? Science 317(5834), 41-42.

Egawa T. and Ooba Y. (1963). Mineralogical studies of some soils in the central highland of vietnam. Soil Science and Plant Nutrition 9(6), 14-20.

FAO (2014). Aquastat: Global information system on water and agriculture. www.fao.org/nr/water/aquastat/data/cf/readPdf.html?f=VNM-CF eng.pdf.

Fernandes H. M. (1997). Heavy metal distribution in sediments and ecological risk assessment: the role of diagenetic processes in reducing metal toxicity in bottom sediments. Environmental Pollution 97(3), 317-325.

Fernandes L. L. and Nayak G. N. (2012). Heavy metals contamination in mudflat and mangrove sediments (Mumbai, India). Chemistry and Ecology 28(5), 435-455.

Ferreira T. O., Otero X. L., Vidal-Torrado P. and Macías F. (2007). Effects of bioturbation by root and crab activity on iron and sulfur biogeochemistry in mangrove substrate. Geoderma 142(1-2), 36-46.

Froelich P. N., Klinkhammer G., Bender M. L., Luedtke N., Heath G. R., Cullen D., Dauphin P., Hammond D., Hartman B. and Maynard V. (1979). Early oxidation of organic matter in pelagic sediments of the eastern equatorial Atlantic: suboxic diagenesis. Geochimica et Cosmochimica Acta 43(7), 1075-1090.

Grellier S., Janeau J. L., Dang Hoai N., Nguyen Thi Kim C., Le Thi Phuong Q., Pham Thi Thu T., Tran-Thi N. T. and Marchand C. (2017). Changes in soil characteristics and C dynamics after mangrove clearing (Vietnam). Science of The Total Environment 593-594, 654-663.

Holloway C. J., Santos I. R., Tait D. R., Sanders C. J., Rose A. L., Schnetger B., Brumsack H.-J., Macklin P. A., Sippo J. Z. and Maher D. T. (2016). Manganese and iron release from mangrove porewaters: $A$ significant component of oceanic budgets? Marine Chemistry 184, 43-52.

Hong P. N. (2001). Reforestation of mangroves after severe impacts of herbicides during the the Viet Nam war: the case of Can Gio. Unasylva (FAO).

Kristensen E. (2008b). Mangrove crabs as ecosystem engineers; with emphasis on sediment processes. Journal of Sea Research 59(1-2), 30-43.

Kristensen E., Bouillon S., Dittmar T. and Marchand C. (2008a). Organic carbon dynamics in mangrove ecosystems: A review. Aquatic Botany 89(2), 201-219. 
Kuenzer C. and Tuan V. Q. (2013). Assessing the ecosystem services value of Can Gio Mangrove Biosphere Reserve: Combining earth-observation- and household-survey-based analyses. Applied Geography 45, 167-184.

Kutscher D., Wills J. D. and McSheehy D. S. (2014). Analysis of High Matrix Samples using Argon Gas Dilution with the Thermo Scientifc iCAP Q ICP-MS. Technical Note 43202, Thermo Fisher Scientific, Bremen, Germany.

Lacerda L., Rezende C., Aragon G. and Ovalle A. (1991). Iron and chromium transport and accumulation in a mangrove ecosystem. Water, Air, and Soil Pollution 57(1), 513-520.

Lacerda L. D., Ribeiro Jr M. G. and Gueiros B. B. (1999). Manganese dynamics in a mangrove mud flat tidal creek in SE Brazil. Mangroves and Salt Marshes 3, 105-115.

Lee S. Y., Primavera J. H., Dahdouh-Guebas F., McKee K., Bosire J. O., Cannicci S., Diele K., Fromard F., Koedam N., Marchand C., Mendelssohn I., Mukherjee N. and Record S. (2014). Ecological role and services of tropical mangrove ecosystems: a reassessment. Global Ecology and Biogeography 23(7), 726-743.

Lewis M., Pryor R. and Wilking L. (2011). Fate and effects of anthropogenic chemicals in mangrove ecosystems: a review. Environmental Pollution 159(10), 2328-2346.

Luong N. V. (2011). Mangrove forest structure and coverage change analysis using remote sensing and geographical information system technology: A case study of Can Gio Mangrove Biosphere Reserve, Hi Chi Minh City, Vietnam. Final report submitted to Rufford Small Grants Foundation, 40pp.

Luong N. V., Tateishi R. and Hoan N. T. (2015). Analysis of an impact of succession in mangrove forest association using remote sensing and GIS technology. Journal of Geography and Geology 7(1), 106.

M. Brander L., J. Wagtendonk A., S. Hussain S., McVittie A., Verburg P. H., de Groot R. S. and van der Ploeg S. (2012). Ecosystem service values for mangroves in Southeast Asia: A meta-analysis and value transfer application. Ecosystem Services 1(1), 62-69.

Ma L. Q. and Rao G. N. (1997). Chemical fractionation of cadmium, copper, nickel, and zinc in contaminated soils. Journal of Environmental Quality 26(1), 259-264.

MacFarlane G. and Burchett M. (2002). Toxicity, growth and accumulation relationships of copper, lead and zinc in the grey mangrove Avicennia marina (Forsk.) Vierh. Marine Environmental Research 54(1), 65-84.

MacFarlane G., Pulkownik A. and Burchett M. (2003). Accumulation and distribution of heavy metals in the grey mangrove, Avicennia marina (Forsk.) Vierh.: biological indication potential. Environmental Pollution 123(1), 139-151.

MacKenzie R. A., Foulk P. B., Klump J. V., Weckerly K., Purbospito J., Murdiyarso D., Donato D. C. and Nam V. N. (2016). Sedimentation and belowground carbon accumulation rates in mangrove forests that differ in diversity and land use: a tale of two mangroves. Wetlands Ecology and Management 24(2), 245-261.

Manceau A., Silvester E., Bartoli C., Lanson B. and Drits V. A. (1997). Structural mechanism of Co2+ oxidation by the phyllomanganate buserite. American Mineralogist 82(11-12), 1150-1175.

Marchand C., Allenbach M. and Lallier-Vergès E. (2011b). Relationships between heavy metals distribution and organic matter cycling in mangrove sediments (Conception Bay, New Caledonia). Geoderma 160(34), 444-456.

Marchand C., Baltzer F., Lallier-Vergès E. and Albéric P. (2004). Pore-water chemistry in mangrove sediments: relationship with species composition and developmental stages (French Guiana). Marine geology 208(2-4), 361-381.

Marchand C., Fernandez J. M. and Moreton B. (2016). Trace metal geochemistry in mangrove sediments and their transfer to mangrove plants (New Caledonia). Science of The Total Environment 562, 216 227.

Marchand C., Fernandez J. M., Moreton B., Landi L., Lallier-Vergès E. and Baltzer F. (2012). The partitioning of transitional metals ( $\mathrm{Fe}, \mathrm{Mn}, \mathrm{Ni}, \mathrm{Cr}$ ) in mangrove sediments downstream of a ferralitized ultramafic watershed (New Caledonia). Chemical Geology 300-301, 70-80.

Marchand C., Lallier-Vergès E. and Allenbach M. (2011a). Redox conditions and heavy metals distribution in mangrove forests receiving effluents from shrimp farms (Teremba Bay, New Caledonia). Journal of Soils and Sediments 11(3), 529-541. 
Marchand C., Lallier-Vergès E. and Baltzer F. (2003). The composition of sedimentary organic matter in relation to the dynamic features of a mangrove-fringed coast in French Guiana. Estuarine, Coastal and Shelf Science 56(1), 119-130.

Marchand C., Lallier-Vergès E., Baltzer F., Albéric P., Cossa D. and Baillif P. (2006). Heavy metals distribution in mangrove sediments along the mobile coastline of French Guiana. Marine Chemistry 98(1), 1-17.

Marchand C., Lallier-Vergès E., Disnar J. R. and Kéravis D. (2008). Organic carbon sources and transformations in mangrove sediments: A Rock-Eval pyrolysis approach. Organic Geochemistry 39(4), 408-421.

Masscheleyn P. H., Delaune R. D. and Patrick Jr W. H. (1991). Effect of redox potential and pH on arsenic speciation and solubility in a contaminated soil. Environmental Science and Technology 25(8), 14141419.

Millaleo R., Reyes-Díaz M., Ivanov A., Mora M. and Alberdi M. (2010). Manganese as essential and toxic element for plants: transport, accumulation and resistance mechanisms. Journal of soil science and plant nutrition 10(4), 470-481.

Morse J. and Luther G. (1999). Chemical influences on trace metal-sulfide interactions in anoxic sediments. Geochimica et Cosmochimica Acta 63(19), 3373-3378.

Murray J. W. and Dillard J. G. (1979). The oxidation of cobalt (II) adsorbed on manganese dioxide. Geochimica et Cosmochimica Acta 43(5), 781-787.

Nguyen B. T., Do T. K., Tran T. V., Dang M. K., Dell C. J., Luu P. V. and Vo Q. T. K. (2018). High soil Mn and $\mathrm{Al}$, as well as low leaf $\mathrm{P}$ concentration, may explain for low natural rubber productivity on a tropical acid soil in Vietnam. Journal of plant nutrition, 1-12.

Nguyen T. T. N., Nemery J., Gratiot N., Strady E., Tran V. Q., Nguyen A. T., Aime J. and Peyne A. (2018). Nutrient dynamics and eutrophication assessment in the tropical river system of Saigon - Dongnai (southern Vietnam). Science of The Total Environment 653, 370-383.

Nickson R., McArthur J., Ravenscroft P., Burgess W. and Ahmed K. (2000). Mechanism of arsenic release to groundwater, Bangladesh and West Bengal. Applied Geochemistry 15(4), 403-413.

Noël V., Juillot F., Morin G., Marchand C., Ona-Nguema G., Viollier E., Prévot F., Dublet G., Maillot F., Delbes L., Marakovic G., Bargar J. R. and Brown G. E. (2017). Oxidation of Ni-Rich Mangrove Sediments after Isolation from the Sea (Dumbea Bay, New Caledonia): Fe and $\mathrm{Ni}$ Behavior and Environmental Implications. ACS Earth and Space Chemistry 1(8), 455-464.

Noël V., Marchand C., Juillot F., Ona-Nguema G., Viollier E., Marakovic G., Olivi L., Delbes L., Gelebart F. and Morin G. (2014). EXAFS analysis of iron cycling in mangrove sediments downstream a lateritized ultramafic watershed (Vavouto Bay, New Caledonia). Geochimica et Cosmochimica Acta 136, 211-228.

Noël V., Morin G., Juillot F., Marchand C., Brest J., Bargar J. R., Muñoz M., Marakovic G., Ardo S. and Brown G. E. (2015). Ni cycling in mangrove sediments from New Caledonia. Geochimica et Cosmochimica Acta $169,82-98$.

Noronha-D'Mello, A. C. and Nayak G. N. (2015). Geochemical characterization of mangrove sediments of the Zuari estuarine system, West coast of India. Estuarine, Coastal and Shelf Science 167, 313-325.

Otero X. L., Ferreira T. O., Huerta-Díaz M. A., Partiti C. S. M., Souza V., Vidal-Torrado P. and Macías F. (2009). Geochemistry of iron and manganese in soils and sediments of a mangrove system, Island of Pai Matos (Cananeia - SP, Brazil). Geoderma 148(3-4), 318-335.

Parvaresh H., Abedi Z., Farshchi P., Karami M., Khorasani N. and Karbassi A. (2011). Bioavailability and concentration of heavy metals in the sediments and leaves of grey mangrove, Avicennia marina (Forsk.) Vierh, in Sirik Azini Creek, Iran. Biological trace element research 143(2), 1121-1130.

Passos E. d. A., Alves J. C., dos Santos I. S., Alves J. d. P. H., Garcia C. A. B. and Spinola Costa A. C. (2010). Assessment of trace metals contamination in estuarine sediments using a sequential extraction technique and principal component analysis. Microchemical Journal 96(1), 50-57.

Perin G., Craboledda L., Lucchese M., Cirillo R., Dotta L., Zanette M. and Orio A. (1985). Heavy metal speciation in the sediments of northern Adriatic Sea. A new approach for environmental toxicity determination. Heavy metals in the environment 2(1), 454-456.

Pickering W. (1986). Metal ion speciation-soils and sediments (a review). Ore Geology Reviews 1(1), 83146. 
Qiu G., Gao T., Hong J., Tan W., Liu F. and Zheng L. (2017). Mechanisms of arsenic-containing pyrite oxidation by aqueous arsenate under anoxic conditions. Geochimica et Cosmochimica Acta 217, 306319.

Rath P., Panda U. C., Bhatta D. and Sahu K. C. (2009). Use of sequential leaching, mineralogy, morphology and multivariate statistical technique for quantifying metal pollution in highly polluted aquatic sediments--a case study: Brahmani and Nandira Rivers, India. Journal of Hazardous and Materials 163(2-3), 632-644.

Ross P. (1975). The mangroves of South Vietnam: the impact of military use of herbicides. Proceedings of the international symposium on biology and management of mangroves. Gainesville, Florida: Institute of Food and Agricultural Sciences, University of Florida.

Sanders C. J., Santos I. R., Barcellos R. and Silva Filho E. V. (2012). Elevated concentrations of dissolved Ba, $\mathrm{Fe}$ and $\mathrm{Mn}$ in a mangrove subterranean estuary: Consequence of sea level rise? Continental Shelf Research 43, 86-94.

Silva G. S. d., Nascimento A. S. d., Sousa E. R. d., Marques E. P., Marques A. L. B., Corrêa L. B. and Silva G. S. d. (2014). Distribution and Fractionation of Metals in Mangrove Sediment from the Tibiri River Estuary on Maranhão Island. Revista Virtual de Química 6(2).

Strady E., Dang V. B., Nemery J., Guedron S., Dinh Q. T., Denis H. and Nguyen P. D. (2017). Baseline seasonal investigation of nutrients and trace metals in surface waters and sediments along the Saigon River basin impacted by the megacity of Ho Chi Minh (Vietnam). Environmental Science and Pollution Research International 24(4), 3226-3243.

Tam N. and Wong Y. (1996). Retention and distribution of heavy metals in mangrove soils receiving wastewater. Environmental Pollution 94(3), 283-291.

Tessier A., Campbell P. G. and Bisson M. (1979). Sequential extraction procedure for the speciation of particulate trace metals. Analytical Chemistry 51(7), 844-851.

Thamdrup B. (2000). Bacterial manganese and iron reduction in aquatic sediments. Advances in microbial ecology, Springer, 41-84.

Thanh-Nho N., Strady E., Nhu-Trang T. T., David F. and Marchand C. (2018). Trace metals partitioning between particulate and dissolved phases along a tropical mangrove estuary (Can Gio, Vietnam). Chemosphere 196, 311-322.

Tuan V. Q. and Kuenzer C. (2012). Can Gio Mangrove Biosphere Reserve Evaluation 2012: Current status, Dynamics and Ecosystem Services Ha Noi, Viet Nam: IUCN, 102 pp.

Ure A. M., Quevauviller P., Muntau H. and Griepink B. (1993). Speciation of heavy metals in soils and sediments - an account of the improvement and harmonization of extraction techniques undertaken under the auspices of the BCR of the commission of the European comminities. International Journal of Environmental Analytical Chemistry 51(1-4), 135-151.

Usman A. R., Alkredaa R. S. and Al-Wabel M. I. (2013). Heavy metal contamination in sediments and mangroves from the coast of Red Sea: Avicennia marina as potential metal bioaccumulator. Ecotoxicology and Environmental Safety 97, 263-270.

Wang Z., Shan X.-q. and Zhang S. (2002). Comparison between fractionation and bioavailability of trace elements in rhizosphere and bulk soils. Chemosphere 46(8), 1163-1171.

Yruela I. (2009). Copper in plants: acquisition, transport and interactions. Functional Plant Biology 36(5), 409-430.

Zhang C., Yu Z. G., Zeng G. M., Jiang M., Yang Z. Z., Cui F., Zhu M. Y., Shen L. Q. and Hu L. (2014). Effects of sediment geochemical properties on heavy metal bioavailability. Environment International 73, 270281.

Zheng Y., Stute M., Van Geen A., Gavrieli I., Dhar R., Simpson H., Schlosser P. and Ahmed K. (2004). Redox control of arsenic mobilization in Bangladesh groundwater. Applied Geochemistry 19(2), 201-214. 